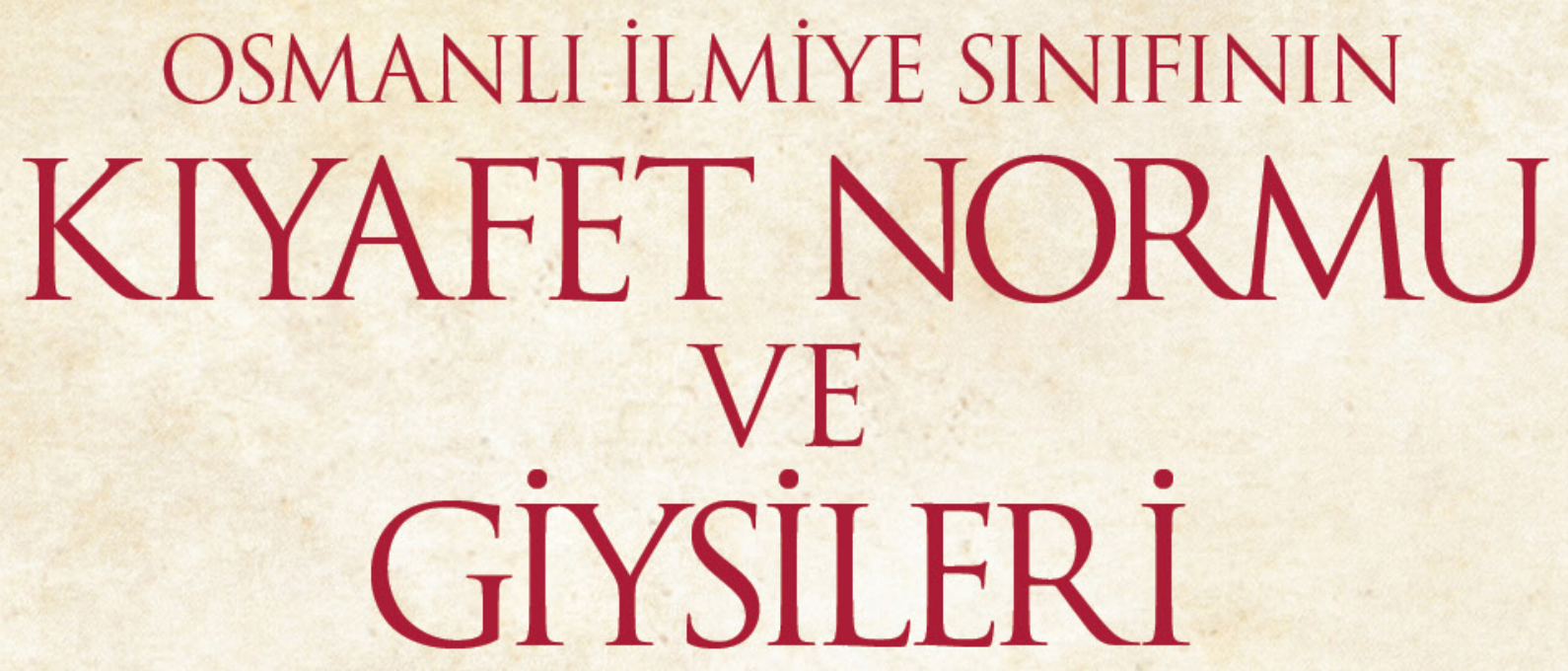

MURAT ÇELIK

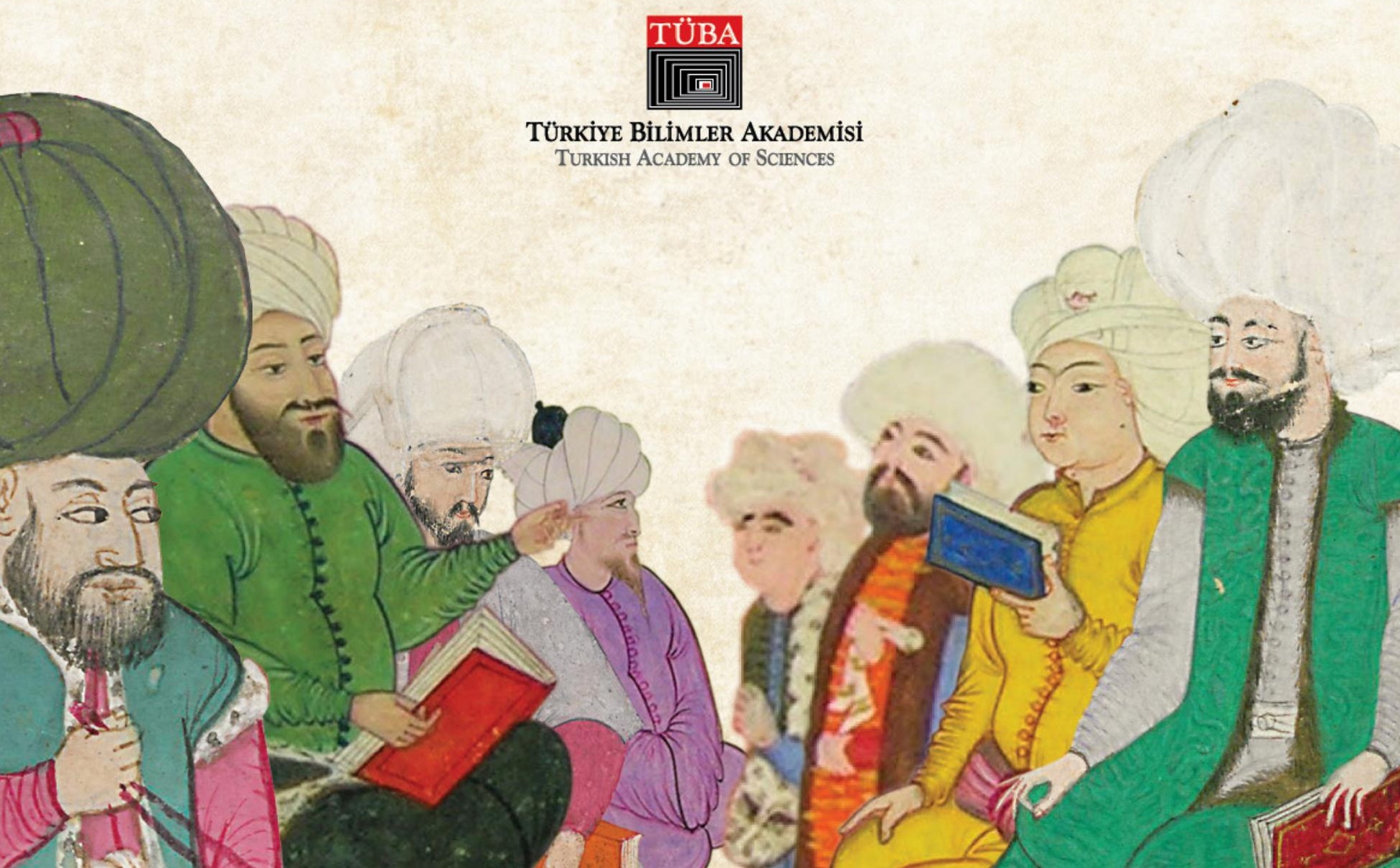




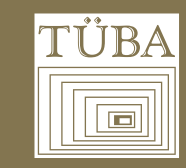

TÜRKiYE BiLIMLER AKADEMisi

$$
\text { TURKISH ACADEMY OF SCIENCES }
$$


Clothing Norm and Attires of the Ottoman Ilmiye Class

Osmanlı İlmiye Sınıfının Kıyafet Normu ve Giysileri

Murat Çelik

Turkish Academy of Sciences Science and Thought Series: 30

Türkiye Bilimler Akademisi Bilim ve Düșün Dizisi: 30

ISBN: 978-605-2249-74-1

DOI: 10.53478/TUBA.2021.016

Ankara, 2021

Hazırlayan / Edited By

Dr. Öğr. Üyesi Murat Çelik

Tasarım ve Uygulama / Design

Murat Acar

Tashih / Proofreading

Siddık Yurtsever

Doç. Dr. Cem Korkut

İletișim ve Koordinasyon / Communication and Coordination Asiye Komut Șanlı

Baskı / Publisher

Tek Ses Ofset Matbaacılık Yayıncılık Org. San. ve Tic. Ltd. Ști.

Kazım Karabekir Cad. Kültur Iș Hanı No: $7 / 11$ - 60 iskitter / Ankara

(c)Türkiye Bilimler Akademisi, 2021.

Bu eserin tüm yayın hakları, Türkiye Bilimler Akademisi' ne aittir.

Yayıncının yazıı izni olmadan kısmen veya tamamen basılamaz ve çoğaltılamaz.

Eserden kaynak gösterilerek alıntı yapılabilir.

(C) Turkish Academy of Sciences, 2021.

All publishing rights of this work belong to the Turkish Academy of Sciences.

It may not be printed and reproduced partially or fully without the written

consent of the publisher. It can be cited by providing full reference.

Kitabın dil, bilim, etik ve hukuk açısından bilimsel sorumluluğu yazara aittir.

Türkiye Bilimler Akademisi' nin sorumluluğu bulunmamaktadır.

The author bears full scientific responsibility for the book in terms of language.

scholarship, ethics and law. Turkish Academy of Sciences has no responsibility whatsoever.

Türkiye Bilimler Akademisi

Turkish Academy of Sciences

Vedat Dalokay Caddesi No: 112

Cankaya 06670 Ankara

ó 3124422903 (pbx)

www.tuba.gov.tr

(c) $(1)(9)$

Bu çalıșma, Creative Commons Atıf 4.0 Uluslararası lisansı (CC BY 4.0) ile lisanslanmıștır Bu lisans, yazarlara atıf yapmak koșulu ile metni paylașmanıza, kopyalamanıza,

dağıtmanıza ve iletmenize; metni uyarlamak ve metnin ticari kullanımına lancak sizi veya eseri kullanımınızı desteklediklerini ileri sürecek șekilde değil) izin verir.

The work (as defined below) is provided under the terms of this creative commons public license ("ccpl" or "license"). This license allows reusers to copy and distribute the material in any medium or format in unadapted form only, for noncommercial purposes only, and only so long as attribution is given to the creator. 


\section{Osmanlı İlmiye Sınıfinın Kıyafet Normu ve Giysileri}

Öğrenci, Kadı, Müftü, Müderris, Nakibüleşraf, Kadıasker, Şeyhülislam GENEL OLARAK KLASIK DÖNEM

\section{Clothing Norm and Attires of the Ottoman İlmiye Class}

Student, Qadi, Mufti, Müderris, Naqib al-Ashraf, Qadiasker, Sheikh al-Islam CLASSIC PERIOD IN GENERAL TERMS

MURAT ÇELIK

Ankara Yıldırım Beyazıt Üniversitesi

Ankara Yıldırım Beyazıt University

ORCID: 0000-0002-9460-8767

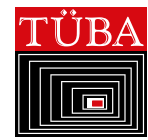





\section{Takdim}

Toplumların maddi ve manevi inşası ancak nitelikli ve yetişmiş insan gücüyle mümkün olmaktadır. Bu gücün sağlam temellere oturarak oluşması ise insan gücünü yetiştiren kadroların niteliği ile doğru orantılıdır. Literatürdeki çalışmalar da ülkelerin kalkınmışlık düzeyi ile eğitim düzeyi arasındaki paralel ilişkiyi gözler önüne sermektedir. Zira, tarihe bakıldığında da mirasını devraldığımız atalarımızın inşa ettiği medeniyetimizin temelleri âlimler tarafindan atılmıştır. Osmanlılar da bu medeniyetin en önemli temsilcilerinden birisi olmuştur.

Osmanlıların uzun ömürlü olmalarını sağlayan hususlardan birisi ilme ve ilim insanlarına verdikleri önemdir. Osmanlılar kuruluşlarından durduruluşlarına kadar âlimlere ve ilim erbabına büyük bir saygı göstermiştir. Toplum içerisinde de âlimler her daim önemli bir konuma sahip olmuştur. Sosyal ve ekonomik ilişkilerin düzenlenmesinde de yine âlimler etkin rol oynamıştır.

Türkiye Bilimler Akademisi (TÜBA) olarak bilim mirasımızın günümüze aktarılması öncelikli çalışma alanlarımızdan birisidir. Dünyamız, günümüzde ulaştı̆̆ kalkınma seviyesini tarihteki tüm medeniyetlerin katkılarına borçludur. Türk-İslam bilim ve kültür mirasının önemli bir kısmını 
oluşturan Osmanlıların da bu medeniyet birikimine etkisi büyük olmuştur. Osmanlıların ilim geleneği çağını ve sonraki dönemleri etkileyen bir niteliği haiz olup günümüzdeki eğitim politikalarının belirlenmesinde de bizlere değerlendirmeler yapma imkânı sunmaktadır. Bu açıdan eğitim ve bilim tarihine çok boyutlu ve disiplinlerarası yaklaşmakta fayda vardır.

Osmanlı bilim ve eğitim tarihi ile ilgili pek çok eser kaleme alınmış olsa da doğrudan Osmanlı âlimlerinin yaşayışlarına temas eden çalışma sayısı kısıtlı kalmıştır. Bu bağlamda Murat Çelik tarafindan kaleme alınan "Osmanl İlmiye Sinufinn Kiyafet Normu ve Giysileri” adlı eserin Osmanlı eğitim tarihini ele alışta yeni bir bakış açısı kazandıracağını umuyorum.

Bu vesile ile başta eserin yazarı Murat Çelik olmak üzere eserin yayımlanmasında emeği geçenlere teşekkürlerimi sunuyorum.

\section{Prof. Dr. Muzaffer Şeker}

TÜBA Başkanı 


\section{Preamble}

Material and spiritual reconstruction of societies is only possible with qualified and educated manpower. Creation of this power, based on solid grounds, is directly proportional to the quality of the cadres which train this manpower. Indeed, studies in literature reveal the parallel ties between the levels of development of countries and their levels of education. Indeed, history tells us that the foundations of our civilizations our ancestors created, and we inherited subsequently was laid by scholars. The Ottomans have been one of the outstanding representatives of this civilization.

One of the reasons why the Ottomans survived for a long time is the importance they attached to science and people of science. The Ottomans revered scholars and people of science from their founding until they were held back. Likewise, scholars always had a significant position in the society. Furthermore, scholars played an active role in regulating the social and economic relations.

As the Turkish Academy of Sciences (TÜBA), it is one of our primary areas of work to transmit our scientific heritage into the present. Our world owes its current development level to the contributions of all civilizations in the history. The Ottomans, which constitute a significant part of the 
Turco-Islamic scientific and cultural heritage, had immense impact on this reservoir of civilization. The scholarly tradition of the Ottomans had a nature that influenced its era and the subsequent periods, and it gives us the opportunity to make assessments for determining today's education policies. In this regard, one should approach the history of education and science, with a multi-dimensional and inter-disciplinary view.

Despite the fact that many studies have been done on the Ottoman science and education history, number of works touching directly upon the lives of the Ottoman scholars have been limited. In this context, I hope that the book titled "Clothing Norm and Attires of the Ottoman Ilmiye Class", authored by Murat Çelik, will introduce a new perspective on tackling the Ottoman education history.

On this occasion, I present my gratitude to all those who contributed to publication of this book, particularly Murat Çelik, the author of the book.

\section{Prof. Dr. Muzaffer Şeker}

TÜBA President 


\section{Ön Söz}

'Mükemmel iyinin düşmanıdır' sözü elinizde tuttuğunuz bu çalışmayı az ya da çok ifade etmektedir. Bu yüzden ne mükemmel ne de iyi olmak iddiasındadır. En önemli amacı neredeyse hiç konu edilmemiş bir alana pencere açarak tartışma başlatmak, Osmanlı ilmiyesinin giysi normuna ilişkin eğitim tarihi bakış açısıyla yeni bir yorum getirmeye çalışmaktır. Böylece Osmanlı yükseköğrenimine ilişkin farklı bir bakış açısının sağlanabileceği ümidi yeşertilmiş olacaktır.

Osmanlılara ilişkin çalışmalar son yarım yüzyıldır dünyanın ilgisini çekse de Osmanlı eğitim tarihinin bu ilgiden yeterince nasiplenememiş olması üzücüdür. Oysa Osmanlı eğitim tarihinin Osmanlı toplumsal yapısını anlamanın temel unsurlarından biri olduğu iddia edilebilir. Bu bakımdan Osmanlı eğitim tarihi anlaşlmadan bu yapının inşa ettiği düzenin anlaşlabilmesinin mümkün olduğu söylenemez. Kuşkusuz belgeler üzerinden yükselen izaha yönelik kronolojik bir yaklaşım veya siyasi bir çerçeve içinde Osmanlı tarihinin ele alınışı da önemlidir; bilhassa araştırmalarda mikro konulara doğru bir eğilimin görülmeye başlanması da mühim sayılabilir. Fakat Osmanlı zihniyetinin kurucu unsurlarının karinelerini içinde barındıran entelektüel tarih ve onun kurucu niteliklerini üreten eğitimin anlaşlması belki hepsinden daha önemlidir. 
Avrupa'da 1950'lerde gelişmeye başlayan yükseköğrenim tarihçiliğinin bir benzerinin günümüz Osmanlı tarihçiliğinde kural ve gelenekleri ile oluştuğu, bağımsız bir disipline karşllı geldiği henüz söylenemez. Elbette Avrupa yükseköğrenim tarihçiliğinin geldiği nokta araştırma alt alanlarını genişletmekle kalmamış, zenginleşmesine de yol açmıştır. Misal olarak Avrupa yükseköğrenim kurumlarındaki kıyafetler bahsi, işaret edilen bu alanlardan biridir. Bugün, üniversitelerdeki törensel cazibenin simgeleri olan akademik kıyafetler hâlâ ilgi çekicidirler. Çünkü cübbeler, kepler, giysilerdeki renkler ve bu görüntüyü tamamlayan diğer ayrıntılar yüzlerce yıllık geleneğin birer devamı niteliğindedirler. Avrupa yükseköğreniminin geliştirerek sürdürdüğü bu geleneğin bir benzerinin Osmanlı medreseleri için de mümkün olduğu söylenmelidir. Çünkü Nizamiye Medreseleri'nden itibaren tesis edilen kıyafet düzenlemeleri Osmanlılara kadar ulaşmış, Osmanlılar da bu geleneği 19. yüzyılın sonlarına kadar sıkı sıkıya korumuşlardır. Bu koruma gerçekten de basit ve cümlenin yeri dolsun kabilinden bir muhafaza ediş değildir. Osmanlıların 18 ve 19. yüzyıllarda gerçekleştirdiği askerî, sosyal ve bürokratik sslahatlar devlet ve toplumsal yapıya nüfuz etmesine, gelenekleri değiştirmesine karşın ilmiyenin, en azından görsel varlık olarak, kıyafetlerini dikkatle muhafaza etmesi dikkat çekicidir. Söz konusu bu durumun yukarıda dile getirilen Osmanlı yükseköğreniminin zihni kurucu unsuru olmasıyla da yakından ilgisi bulunmaktadır.

Osmanlı zihniyetini kurup inşa edenler Osmanlı uleması ve onun kurumsal yapısı olan ilmiyesidir. Askerî sınıf içinde yer alan Osmanlı ilmiyesini oluşturan ulema ise işlevsel anlamda farklı alt sınıflara ayrılsa da bağlı oldukları merkez, Osmanlı medresesidir. Bu bakımdan Osmanlı medreseleri Osmanlı ilmiyesinin ve entelektüel zihninin ocağıdır; dolayısıyla kendisine ait bir gelenek, görenek ve kıyafet biçimi mevcuttur. Kıyafetler ise Osmanlı ilmiyesini tüm unsurlarıyla devlet içinde görünür kılıp konumunu tescil eder. Osmanlı ilmiyesinin kıyafet düzenlemeleri ve farklılıkları kendisini en alt seviye olan öğrencilikten en üst makam şeyhülislamlığa değin kuvvetli bir biçimde gösterir. Farklılıklar ve makam düzenlemeleri kıyafetlerin tasarım ve renkleriyle de belirgin kılınır. Böylece toplumsal yapı içinde fark edilmeleri kolaylaştırılmış olur. 
Osmanlı ilmiyesine ait kıyafetlerin konu edildiği bu araştırmayla üç alana katkı yapılması hedeflenmiştir. Öncelikle Osmanlı ilmiyesine yönelik kıyafet normunun ortaya çıkarılması ve dolayısıyla da teorik bir zeminin kurulması amaçlanmaktadır. Kuşkusuz Osmanlı ilmiyesi kıyafet normunun felsefi bir arka planı ve gerekçesi bulunmaktadır. Çalışmada söz konusu bu teorik plan ve gerekçenin tasarımı tartışılmıştır. Diğer bir hedef ise Osmanlı ilmiyesine ait kıyafetlerin, ileride yapılacak çalışmalara kaynaklık etmesi bakımından, bir tasnife tabi tutulmasıdır. Tasnif çalışmasıyla ilmiye kıyafetleri sınıflandırılacak, böylelikle kıyafetlerin birbirleriyle olan ilişkileri kurulabilecektir. Üçüncü ve son hedef ise Osmanlı yükseköğrenim çalışmalarında ilmiye kıyafetlerinin bir alt disiplin olarak teşekkül etmesine zemin hazırlamaktır. Çünkü böylelikle mukayeseli çalışmalara kaynaklık edecek bir alt disiplin kurulabilecektir.

Çalışmaya ait somut çıktıların elde edilebilmesinde iki alanın eksik kaldığı itiraf edilmelidir. İlkin üzerinde çalışlan giysi formlarına ait patronların çıkarılması düşünülmüştür. Keza kalıpları çıkarılmış giysi ve ayakkabıların bu patronlara göre dikilmeleri de arzu edilmiştir. Ancak finansman ve zaman yetersizliği bu iki hedefin gerçekleştirilmesine imkan tanımamıştır.

Eserin yayına hazırlanmasında kıymetli katkılarından ötürü başta değerli başkanı Prof. Dr. Muzaffer Şeker olmak üzere Türkiye Bilimler Akademisine şükranlarımı sunuyorum.

Son bir söz olarak, yardımlarını esirgemeyip cömertçe mukabelede bulunan adları mahfuz dost, arkadaş ve büyükler saygıyla anılmalıdır.

Gayret bizden...

\section{Murat Çelik}

02 Nisan 2021, Çinarcık 


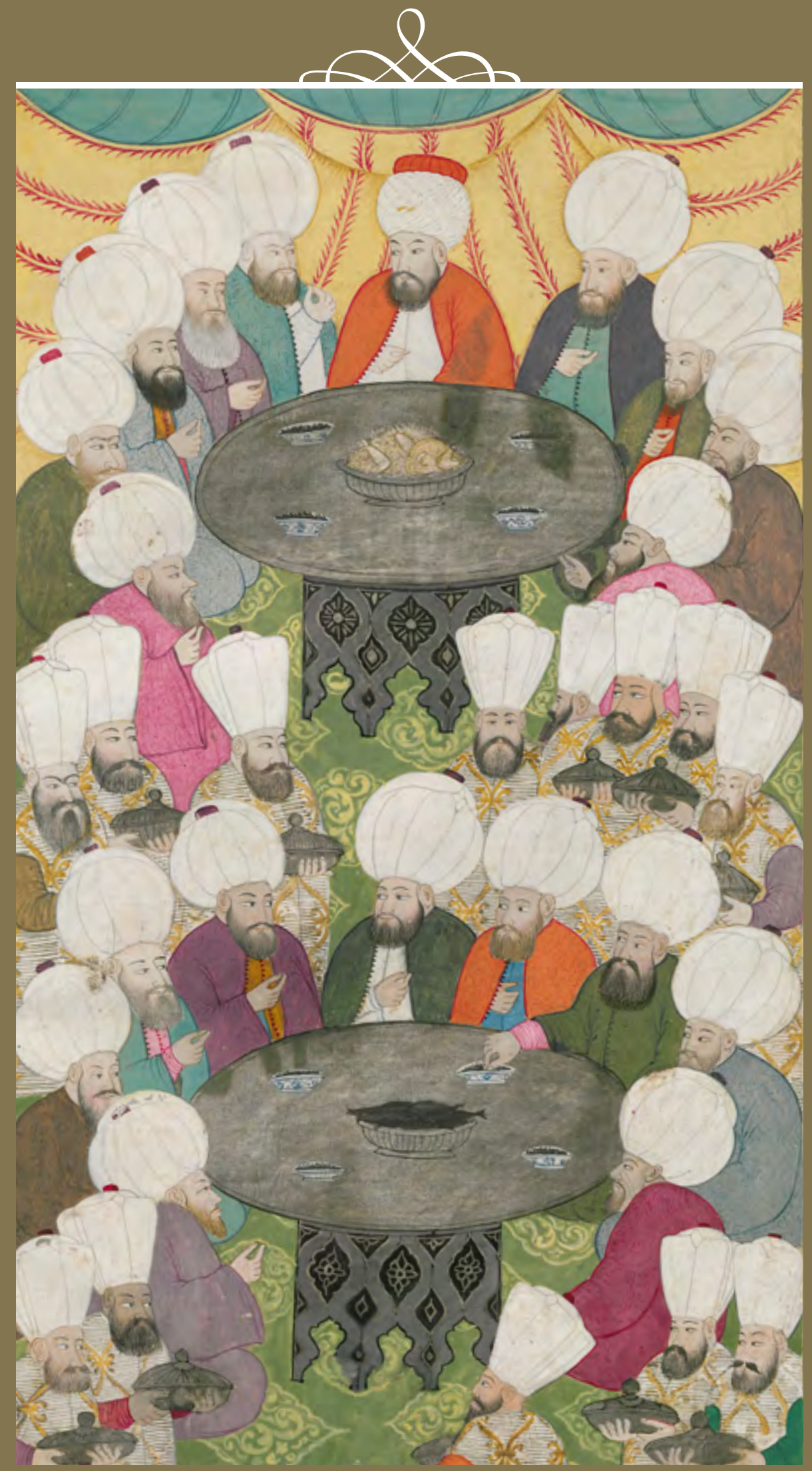

RESiM 1. Müderrislerin Ziyafeti; Șenliğin 3. Günü

Seyyid Vehbi Hüseyin bin Abdullah, Surname-i Vehbi, TSMK, 3. Ahmet Kitaplığı 3594, 73b. 


\section{Foreword}

The expression "perfect is the enemy of good" more or less describes this book in your hands. Thus, it claims to be neither perfect, nor good. Its most important aim is to open a new window and start a new discussion on a field that has almost never been tackled, by introducing a new understanding to it, with an education history perspective. Thus, the hope that a different perspective on the Ottoman higher education can be established will have been flourished.

Despite the fact that studies on the Ottomans have attracted global attention in the last half century, it is saddening that the Ottoman education history has not gotten its share in this interest. In fact, one can argue that the Ottoman education history is the key to understand the Ottoman social structure. In this regard, understanding the order constructed by this structure cannot be deemed possible without understanding the Ottoman education history. Surely, addressing the Ottoman history with a chronological approach aiming at elucidation, built upon documents, or within a political framework is important as well; it can also be deemed important that a trend is observed towards micro subjects in studies. However, understanding the intellectual history which contains the presumptions of the founding elements of the Ottoman mindset, and the education which produces its founding qualities, may be more important than anything else. 
One cannot claim that higher education historiography, which has commenced in Europe in the 1950s, has established itself in the Ottoman historiography, with all its rules and traditions, and that it corresponds to an independent discipline. Indeed, the level that the European higher education historiography has attained has not only expanded the sub-domains of study, but also enriched it. For instance, issue of clothing in the European higher education institutions is one of the aforementioned fields. Today, academic attires, which are the ceremonial attractions in universities, are still interesting. Because gowns, caps, colors on attires and other details that complement this scene, are a continuation of hundreds of years of tradition. One should note that a tradition that is similar to what the European higher education has developed and sustained is also possible for the Ottoman medreses. Because clothing regulations established after the Nizamiye Medreses was extended to the Ottomans and the Ottomans strictly preserved this tradition until the end of the 19th century. This preservation, indeed, is not a simple and superficial one. Despite the fact that the military, social and bureaucratic reforms that the Ottomans made in the 18th and 19th centuries penetrated into the state and social structure and altered traditions, it is interesting that the ilmiye class maintained its attires, at least as a visual entity. This is closely related to the fact that it is the founding intellectual element of the Ottoman higher education, as stated above.

Those who founded and built the Ottoman mentality is the Ottoman ulema and the ilmiye class, which is its institutional structure. Despite the fact that ulema, which constitutes the Ottoman ilmiye class within the imperial administrators class is divided into different sub-classes, the center they are affiliated is the Ottoman medrese. In this regard, the Ottoman medreses are the center of the Ottoman ilmiye class and its intellectual mentality; therefore, it has its own tradition, customs and clothing form. And attires make the Ottoman ilmiye visible within the state with all its elements, and reiterate its status. The clothing regulations and differences of the Ottoman ilmiye class manifest itself strongly from studentship, which is the lowest level, to the office of the sheikh al-Islam, the highest post. Differences and 
status regulations are made distinct through the design and colors of attires as well. Thus, they are rendered easily distinguishable in the society.

With this study, covering the attires belonging to the Ottoman ilmiye class, it is aimed to provide contribution to three fields. Firstly, it is aimed to unfold the clothing norms of the Ottoman ilmiye class, and hence to establish a theoretical base. Surely, the clothing norm of the Ottoman ilmiye class has a philosophical background and reason. The design of this theoretical plan and reason is discussed in this study. Another target is to classify attires belonging to the Ottoman ilmiye class, to serve as a source for future studies. With this classification effort, the ilmiye attires will be sorted out and thus, the attires will be inter-related. The third and the last aim is to pave the way for establishment of the Ottoman ilmiye class attires as a sub-discipline in the Ottoman higher education studies. Because a sub-discipline that will serve as a source for comparative studies can be established as such.

One should admit that two fields are missing in attaining concrete outputs of the study. It was first conceived to extract the patterns of the dress forms studied. In fact, it was desired to stitch the clothes and shoes as per these patterns. However, lack of time and financing rendered realization of these two goals impossible.

I would like to express my gratitude to Turkish Academy of Sciences, and particularly its President, Prof. Dr. Muzaffer Şeker, for their valuable contributions in preparing this publication.

Lastly, friends and or seniors, whose names are secluded herein, should be remembered with reverence for not having refrained to support and generously contributing to this work.

Effort is on us...

\section{Murat Çelik}

02 April 2021, Çınarcık 


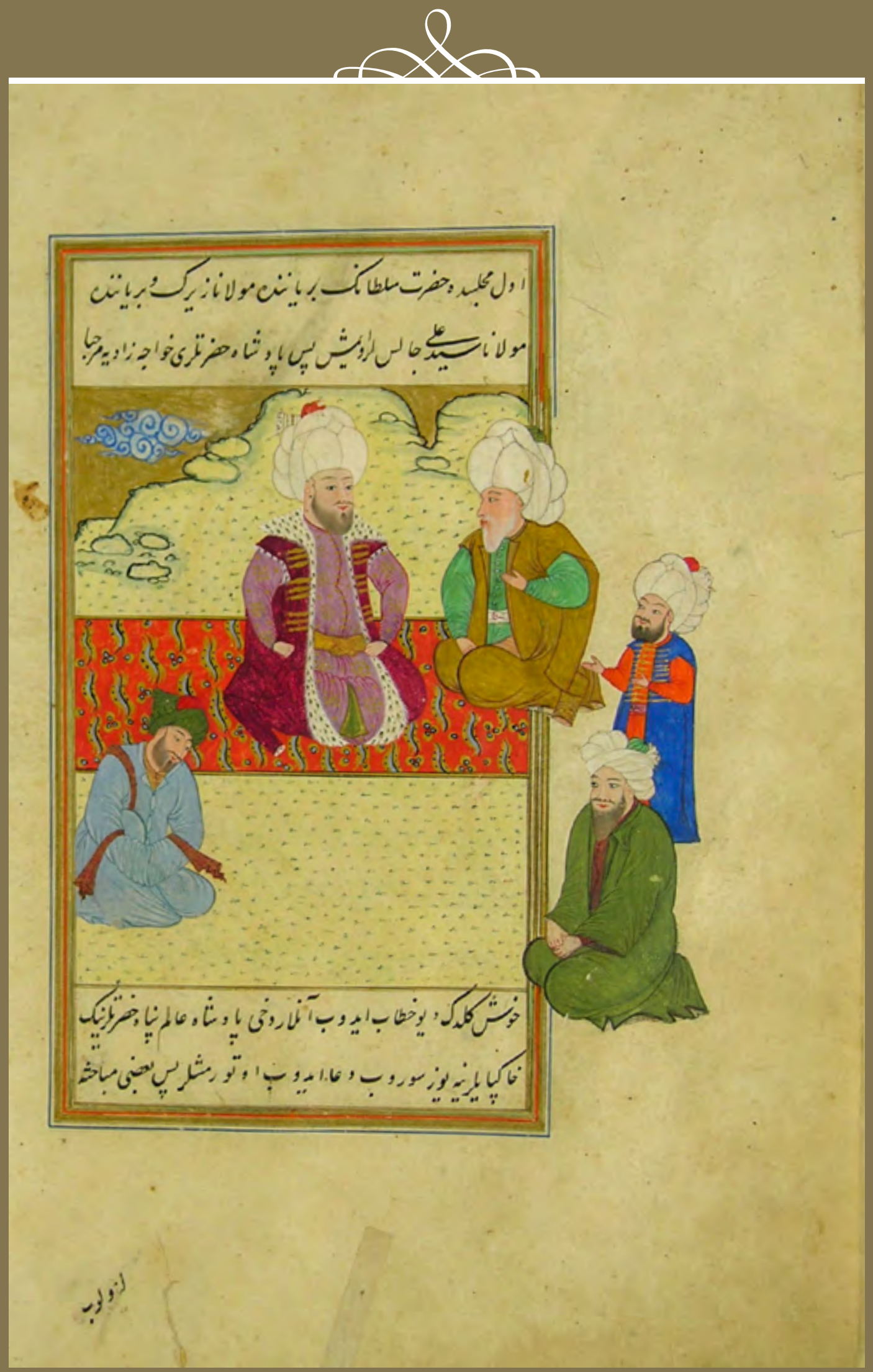

REsiM 2. Fatih Sultan Mehmed, Molla Zeyrek, Hocazade, Seyyid Ali ve Mahmud Pașa Muhtesibzade Mehmed Belgradi, Tercüme-i Șakaiku'n-numaniyye, TSMK, Hazine 1263, 90b. 


\section{Geniş Özet}

Görünüm ve görevler birlikte değerlendirildiğinde kıyafetler resmi görevlerin somutlaştırılmasında önemli sembollerden biri olmuştur. Avrupa üniversitelerine ilişkin tarihi kayıt ve verilerden yola çııılarak kıyafet normlarına ilişkin bir literatür meydana getirilmiştir. Bununla birlikte Osmanlı ilmiye sınıfi için de benzer bir normdan söz edilse de literatürden bahsetmek mümkün değildir. Dolayısıyla bu çalışmanın amacı, Osmanlı ilmiye sınıfının kılık kıyafeti hakkında genel bir tasnif yapmak ve bu tasniften hareketle bir tartışma başlatmaktır. Çalışma üç ana bölümden oluşmaktadır. Birinci bölümde giyim kuşamın antropolojik ve sosyolojik temelleri ele alınmakta, Osmanlı düzeniyle bağlantısı kurulmaktadır. İkinci bölümde Osmanlı ilmiye sınıfının kıyafet normlarını benimsediği ve meşruiyetini vurguladığı tarihi arka plana odaklanılmaktadır. Üçüncü ve son bölümde ise Osmanlı ilmiye sınıfının giyim biçimleriyle ilmiye mensuplarının bireysel tarzları ele alınmakta, elde edilen bilgiler birbiriyle ilişkilendirilmektedir.

Genel olarak ulema, özel olarak da medreselilere ait kıyafetlerin Osmanlı eğitim tarihinin bir meselesi olduğuna şüphe yoktur. Ancak, bu meselenin aydınlığa kavuşturulması iki bakımdan çok kolay değildir. Bu nedenlerin 
başında dönemlerinden bugüne ulaşmış yeterince nitelikli kıyafet koleksiyonlarının bulunmayışıdır. Elbette çeşitli müze koleksiyonlarında giyim ve kuşama dair kimi örnekler mevcutsa da bu örnekler ulemaya ait olmadığı gibi son dönemlere ilişkindir. Diğer yandan müze koleksiyonlarında yer alan kıyafet tarihine ait örnekler de saray mensuplarma ait olanlardan müteşekkildir. O yüzden somut ve birincil kıyafet kaynakları üzerinden bir literatür oluşturmak mümkün görünmemektedir.

Dolayısıyla yapılabilecek tasnif, arşiv belgeleri ve kroniklerdeki nakillere, tezkirelerdeki izahlara, kanunnamelerdeki emirlere, yazmalarda yer verilen minyatürlere ve yabancı ressam ve yazarların tasvir ettikleri gravür ve resimlere muhtaç kalacaktır.

İlmiye mensuplarının moral olduğu kadar şekil şartları bakımından da Hz. Muhammed'e benzemeye çalışacaklarını tahmin etmek zor olmasa gerekir. Zaten bu bakımdan Hz. Muhammed'in yaşantısı her hali ile örnek alınmış ve bu örnek alma Müslümanlara da tavsiye edilmiştir. İlmiye ise her hal ve şartta bu örnekliği hem davranış hem de şekil bakımından bünyesinde görünür hale getirmeye çalışmıştır.

Yukarıda işaret edilen hususlardan ötürü Osmanlı ilmiyesinin kıyafet normunun kendiliğinden ortaya çıkmadığını tahmin etmek zor olmamalıdır. Diğer pek çok alanda olduğu gibi ulema sınıfının giyiminde de tevarüs edilen bir geleneğin varlı̆̆ından söz edilebilir. Müslümanların devletlerini kurmaya başlamasıly bürokratik yapılar bu düzeni takip etmiştir. Bürokratik düzense beraberinde kurumsallaşmayı getirmiş olmalıdır. Müslümanların kurduğu ilk devletler olarak Emeviler ve Abbasiler bürokratik düzeni belli bir olgunluğa getirerek bu kültürü kendilerinden sonra hükümran olan devletlere aktarmışlardır. Bölgedeki en önemli müesses nizam olan Selçuklular ise Osmanlıların kurucu nüvesini içinde barındırmaktadır. Dolayısıyla devlet geleneğinde olduğu gibi sosyal ve kültürel düzenin devamı ilk devletlerden bir silsile olarak Osmanlılara geçmiştir.

Orhan Gazi zamanında ulema beyaz, saray hizmetkarları kırmızı, kalemiye mensupları sarı ve diğer kimseler ise siyah giymekteydiler. Ancak 
Yıldırım Bayezid'den sonra beyaz askerlerin, kırmızı ise saltanatın alameti olarak kullanılmaya başlanmıştır.

Osmanlı ulemasının giydiği kıyafetlerin gündelik ya da resmi bir şekilde kesin olarak ayrılmaları eldeki verilerin yetersizliği nedeniyle mümkün değildir. Bu yüzden çok az malumat kalıntısı haricindeki verilerden Osmanlı ulemasının kıyafet türlerine ilişkin net bir ayırım yapmak gerçekçi olmaz. Bununla birlikte yine de bir fikir vermesi için en azından fonksiyonuna göre kıyafetlerde bir tasnife gidilebilir. Özellikle Osmanlı ulemasının, genel olarak da kişilerin giyimi söz konusu olduğunda nasıl bir tasnife gidilmesi gerektiği meselenin ele alınmasını kolaylaştıracaktır. Söz konusu kolaylaştırma hem teorik hem de pratik niteliklidir. Çünkü ulema kıyafetlerini anlamaya çalışırken ve birbirleriyle ilişki kurarken bir tasnifin takibi faydalı olacaktır. Bu çerçevede Osmanlı ulemasına ait kıyafetleri başlıklar, dış kıyafetler, iç kıyafetler ve ayakkabılar olmak üzere dört [4] ana başlık altında sinıflandırmak makul sayılmalıdır. Bu tasnife göre:

i. Başlık: Ulemanın başına giydiği sarık, kavuk, terlik, takke, örf ve benzerleri başlıkları meydana getirmiştir.

ii. İç Kıyafet: Dış kıyafetin üzerine giyilen kıyafetlerdir; farklı nitelik ve kalitelerdeki iç donu, don, gömlek, cepken, entari, kamis, kuşak, şal, çakşır ve benzerleri anlamına gelmektedir.

iii. Dış Kıyafet: İç giyimin üzerine giyilen, birden fazla olabilen ve kimi zaman tören niteliğindeki zamanlarda tercih edilen klyafetlerdir. Biniş, kürk, ferace, kaftan, kebe, aba, maşlah ve cübbe bunların belli başlılarıdır.

iv. Ayakkabı: Pabuç, edik, mest ve benzerleri ise ulemanın ayak giyimini oluşturmuştur.

Osmanlı uleması kadar askerî sınıfin giyimi söz konusu olduğunda ilk unsur başlıktır. Gerek iklim şartlarından korunmak gerekse sosyal konumu ifade için başlık birer araç niteliğindedir. Yukarıda da ifade edildiği üzere başlı̆̆ın kendisi bir hiyerarşi simgesi olduğundan renk ve farklılık gösterebilmektedir. Osmanlı toplumunda en alt kademeden en üst mevkie değin 
herkes bir başlık kullanmıştır. Başlık bir giyim yahut aksesuar olarak ele alındığında hem malzeme hem de unsurları bakımından ayrı ayrı değerlendirilebilir. Bu çerçeveden bakıldığında başlık öncelikle başa giyilen kavuk, takke, terlik, tepelik ve benzerlerinin yanı sıra üzerlerine sarılan sarık ve sarığın duruma göre omuzlara sarkan ucu olan taylasandan müteşekkildir. Başlangiçta dokuma kumaş ya da dövülmüş keçeden mamul terlik veya kavuk temel işlevi görürken sonrasında buna sarık ve taylasan da ilave olunmuştur. Kavuğun etrafina sarılan uzun ve duruma göre ince, kalın ya da işlemeli veya sade tülbent-şala ise sarık denilmiştir.

Osmanlı ilmiyesinin kıyafetlerinde diğer bir unsuru ise dış giyim olarak cübbe ya da cübbe üstüne giyilen kaftanlar oluşturmaktadır. Açıkçası Osmanlı ulemasının giyim pratikleri alanında hem tür hem de isim konusunda karışıklıklarla karşılaşılmaktadır. Öyle ki çoğu defa cübbe ile bir ağırlık olarak biniş, kaftan veya hilatin karıştırılması son derece olağandır. Genel bir şekilde değerlendirmek mümkün olursa ulemanın asıl üst giysisinin cübbe olduğu belirtilebilir. Cübbenin kullanışlı bir boyut ve nitelikte olması onu ulemanın ders, fetva ya da mahkemede rahatlıkla kullanabileceğini akla getirmektedir. Bu yüzden cübbe gündelik giysi şeklinde telakki edilebilir. Ne var ki merasim kıyafeti olmak yanında sultanın gözde veya sadık bendelerinin temsili için çeşitli biçimlerde imal edilmiş kaftanlar ise cübbe üstüne giyilen başka bir üstlüktür. Her halükarda birbirini takip eden üstlüklerde izlenecek sıra cübbe $>$ biniş $>$ ferace $>$ kaftan şeklindeki bir silsiledir.

Cübbenin altına muhakkak bir içlik olarak entari ya da mintan giyilmekte, böylelikle bir iç kıyafetine yer verilmektedir. Bunların türleri farklı olmakla birlikte genellikle bele kadar düğme ile açılıp alttan giyilmeye uygun kıyafetlerdir. Kolları uzun olup duruma göre bileklere dek uzayan bölgelerde manşetlerle daraltılmışlardır. Entarilerde ise ayağa dek uzayan bu giysiler kimi zaman mintanlarda olduğu gibi bele, kimi zaman da ayağa dek uzayan düğmelerle kapatılmıştır. Genel olarak açılmasının yanı sıra kullanımda kolaylık sağlaması bakımından belden bir şal ya da kuşakla sıkıştırılarak üstüne cübbe ya da mevsimine göre bir üstlük giyilmiştir. 
Giyimi tamamlayan dördüncü ve son unsur ayakkabılardır. Kullanım biçimlerine uygun olarak farklı şekillerde adlandırıldıkları görülmektedir. Misal olması bakımından bu adlandırmalara sahtiyan, pabuç, iç edik, mest-pabuç, uzun konçlu çizme, kısa konçlu bot, terlik, çedik ve başmak misal olarak verilebilir. Ayak giyimi olarak başmak ise yemeniye benzeyip üstü açık ayak giysisine denilir. Siyah sahtiyandan yapılan bu giyimin arka tarafi sert olup terlik gibi kullanılmasının mümkün olmadığı öğrenilmektedir. 



\section{Expanded Summary}

As it is known, clothes are one of the important symbols in the concretization of official duties. In other words, clothing and appearance can be considered along with other components. When European universities have agreed that the dress code is considered as relevant historical data, thus a literature has been produced. However, the Ottoman ilmiye class developed a dress norm in the classes itself as well as classes such as sheikh al-islam, qadi, and müderris. But, unfortunately, the dressing arrangements of the Ottoman ilmiye class have not been studied yet. Therefore, the aim of this study is to make a general classification about the dress code of the Ottoman ilmiye class and to start a discussion based on this classification. The study consists of three main chapters. In the first chapter anthropological and sociological foundations of clothing and attire will be discussed and a connection will be established with the Ottoman establishment. In the second part it will be focused on the historical background that the Ottoman ilmiye class has adopted the norms of dresses and emphasizes its legitimacy. In the third and the last chapter the information about the dressing types of the Ottoman ilmiye class and the clothing of the individual units will be connected with each other. 
There is no doubt that the ulema in general, and the clothing style in the medrese in particular, are matters of the Ottoman educational history. However, unfolding this topic is not easy in two respects. One of the reasons for this is, that there are not sufficient clothes collections in good shape that have reached today. Although these examples of clothing which can be found in museums, neither belong to much older time periods, nor do they refer to the ulema style. Also, those clothes only belong to members of the palace. Therefore, it is not possible to create a literature on concrete and primal clothing sources.

Therefore, classifying those clothes has to be done based on archival documents and transcriptions in chronicles, narratives in scripts, orders in the law, miniatures given in manuscripts, and engravings and illustrations depicted by foreign painters and writers.

The Ottoman ulema members, as well as in terms of morals as in terms of shape probably tried to resemble the Prophet Muhammad, which would not be difficult to guess. In this respect the Prophet Muhammad's life is exemplary in every way, and this example was also recommended to Muslims. In any case, the ulema tried to make this example visible within its style in terms of both behavior and shape.

In this respect, it is not difficult to guess that the dressing norm of the Ottoman ilmiye class did not appear spontaneously. As in many other areas, there is a tradition in the clothing of the ulema class. The bureaucratic structures followed this concept when Muslims started to establish their state. The bureaucratic order probably brought along a certain institutionalization. The first states established by Muslims, e.g. by the Umayyads and Abbasids, brought the bureaucratic order to a certain maturity and transferred this culture to the states which were visible to them. The Seljuks, the most important establishment in the region, are the founders of the Ottomans. Therefore, the continuation of the social and cultural order as in the state tradition was passed on to the Ottomans as a model from the first states.

During the time of Orhan Gazi, the ulema was dressed in white, palace servants were dressed in red, the administrational and scribal were dressed 
in yellow and others in black. However, after Yıldırım Bayezid, soldiers started to use white whereas red was becoming more and more the colour of the sultanate.

It is not possible to conclude if the clothes worn by the Ottoman ulema were clearly separated into official and private attire due to the lack of available information. Therefore, it is not realistic to make a clear distinction between the types of clothes of the Ottoman ulemas from some information. However, in order to give an idea, at least according to the function of their clothes some classifications can be made. Keeping in mind that the Ottoman ulemas were generally concerned about the dressing of the people, it will be easier to address this issue which is both theoretical and practical. Because while trying to understand ulema clothes and establishing a relationship with each other, it will be useful to follow a classification. Within this framework, it is reasonable to classify the clothes of the Ottoman ulema under the titles of headgear, inner clothing, outer clothing and shoes like in the following:

i. Headgear: Sarık [turban], kavuk [quilted turban], terlik [cap], takke [skullcap], örf [ceremonial high turban] and other clothing items the ulema was wearing on his head generally created certain styles of tradition among the population.

ii. Inner Clothing: Outfits worn on the outfit, it means iç donu [internal frost], don [frost/underpants], gömlek [shift], cepken [vest], entari [dress], kamis [tunic], kuşak [belt], şal [shawl], çakşır [trouser] and the like in different qualities and quantities.

iii. Outer Clothing: Clothing worn on inner clothing. It can be more than one piece and were sometimes preferred during ceremonial times. Biniş [formal overcoat], kürk [fur], ferace [loose full-length overcoat], kaftan [ceremonial robe], kebe [felt], aba [coarse wool cloth], maşlah and cübbe [robe] are the main ones.

iv. Shoe: Pabuç [shoe], edik [sandal], mest [under-shoes] and so on formed the ulema's foot wear. 
Firstly this book will deal with the topic of the headgear which was also an important issue for the bureaucrat class [askerî sinif] and not only for the Ottoman ulemas. It serves the purpose of protection within the climatic conditions as well as that of a marker in terms of social position and title. As mentioned above, the title itself is a symbol of hierarchy, so it may vary in color and form. In Ottoman society, everyone used a title from the lowest to the highest. When the title is connected to a clothing or an accessory, it can be considered separately for both its material and its facts. From this perspective, the headgear is primarily composed of takke, terlik, tepelik [small turban] and the like, as well as those parts of the turban that were - sometimes, not always, depending on the ocassion - hanging down onto shoulders. Cap or quilted turban made of woven fabric or hammered felt was used as the base, followed by the addition of turban and taylasan. It is called the sarik, which is a long textile wrapped around the quilted turban and is thin, thick or embroidered.

Another element of the clothing of the Ottoman ilmiye is the kaftans which are worn as robes or on the robes. Obviously, in the field of clothing practices of the Ottoman scholars, there is confusion about both genre and name. So much so that it is not surprizing that very often the binis, the kaftan and the hil'at [honour robe], in terms of extra clothing to put on top of the robe, are being consfused with each other.

If it is possible to evaluate in a general way it can be stated that the ulema's upper top is a robe. The fact that the robe has a useful size and quality suggests that it can be easily used in in school, the fatwa or the court. Therefore, the robes can be considered in the form of casual clothing. However, besides the ceremony outfit, the kaftans are produced in various forms for the representation of the sultan's favorite or loyal items. In any case, the sequence to be followed in successive tops is a cübbe $>$ biniş $>$ ferace $>$ kaftan.

Underneath the robe, an inner clothing in form of a mintan [shirt] is worn. Although there are different types, usually the style is that there are 
buttons up until the waist and thus it is to be put on from the bottom. They have long sleeves and are narrowed by cuffs around the wrists. This sort of garment that extends to the feet was decorated with buttons all the way down to the feet or just only around the waist area. In general, in terms of more easy dressing, they put a shawl on the waist part or a belt with a waist wrap to be worn with a robe depending on the weather season.

The fourth and last element that complements the clothing are the shoes. It seems shoes have been given different names in accordance to their design. Examples are sahtiyan [saffian], pabuç [shoe], iç edik [inner sandal], mest-i pabuç [under-shoes], uzun konçlu çizme [long cropped shoes], kısa konçlu bot [short cropped shoes], terlik [slippers], çedik [sandal] and başmak [shoes] As a foot-garment the black coloured başmak was used as an open-toed garment and looked like a yemeni [sandal]. Due to its solid back it was not possible to be used as a slipper. 



\section{İçindekiler}

Takdim ……

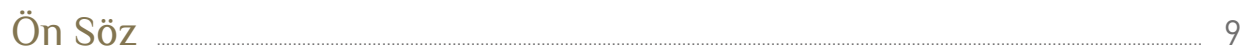

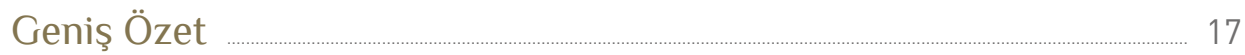

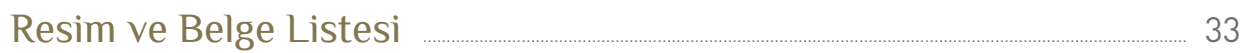

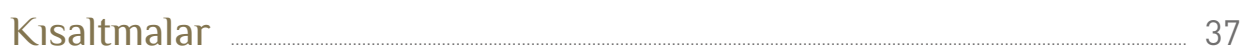

Giriş

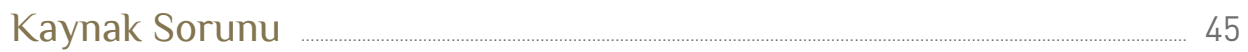

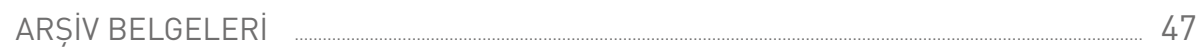

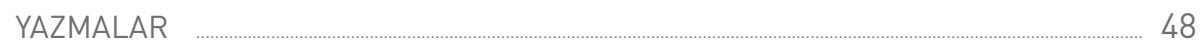

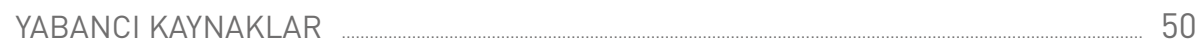

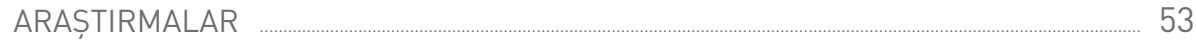

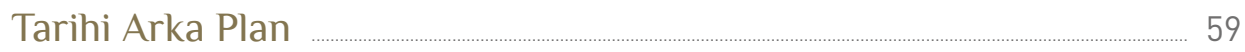

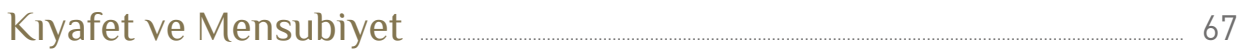


Giysiler ..._. 95

BAȘLIK …_ 96

DIȘ GIYYM . _ _ _ _.... 111

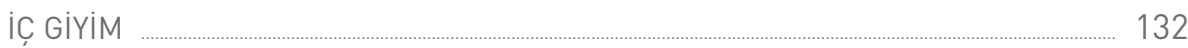

AYAKKABI _.. 141

Osmanlı İlmiye Sınıfının Giysileri _..._._. 153

ÖĞRENCI (SUHTE-DANIȘMENT) _..._______ _ 160

KADI ... 189

MÜFTÜ _ — 198

MÜDERRIS _... 202

NAKIBÜLESTRAF _.. _ 218

KADIASKER _. 222

ȘEYHÜLISLAM _..._ _ _ _ _ _ _ 231

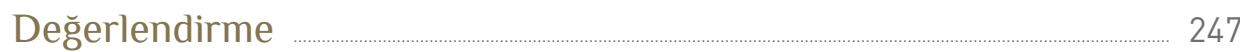

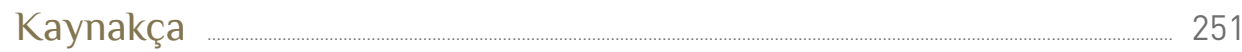

Dizin ... 267 


\section{Table of Contents}

Preamble

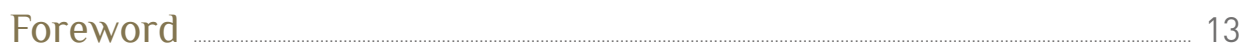

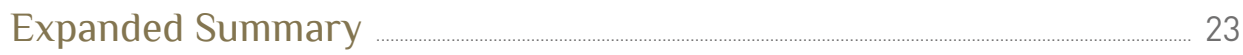

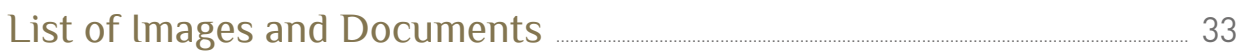

Abbreviations …………………

Introduction ……

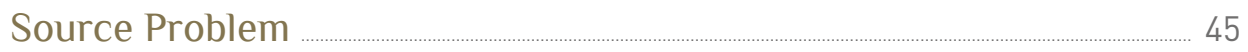

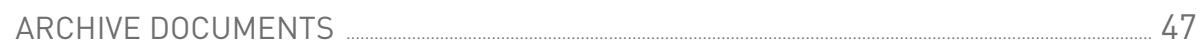

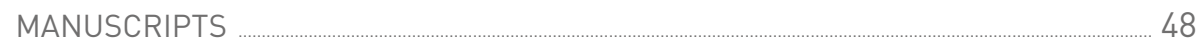

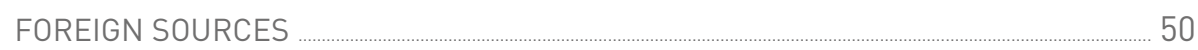

STUDIES ............................................................................................................... 53

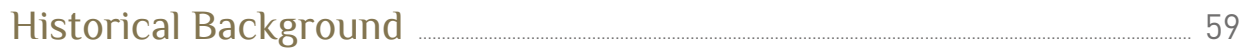

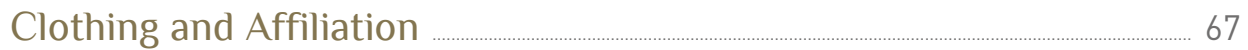




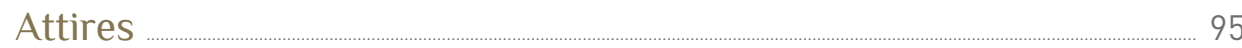

HEADDRESS ..._. _ n

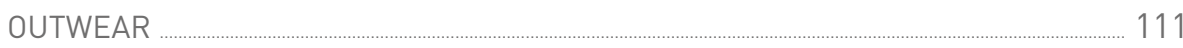

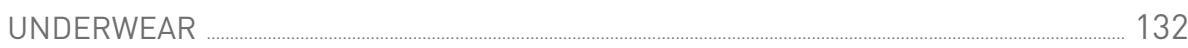

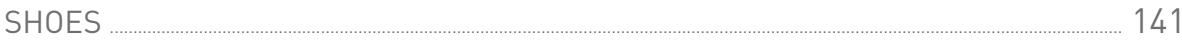

Attires of the Ottoman İlmiye Class …… 153

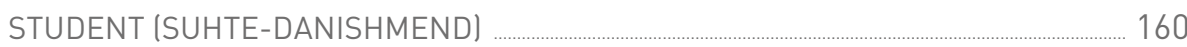

QADI _... _ _ 189

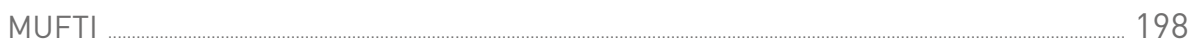

MÜDERRIS ...._.

NAQIB AL-ASHRAF _..__._._._._._._._._. 218

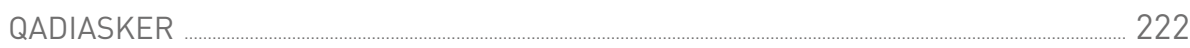

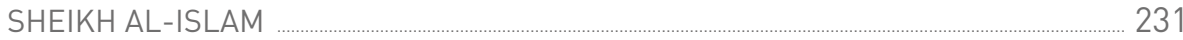

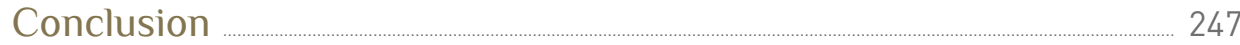

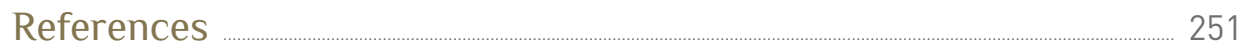

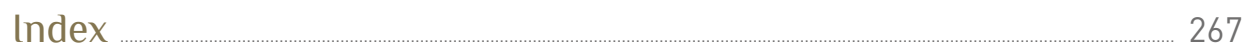




\section{Resim ve Belge Listesi}

\section{RESIMLER}

RESiм 1. Müderrislerin Ziyafeti; Șenliğin 3. Günü _..................................................................................................... 12

Resim 2. Fatih Sultan Mehmed, Molla Zeyrek, Hocazade, Seyyid Ali ve Mahmud Pașa ........................ 16

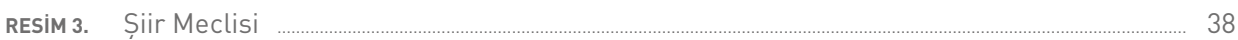

Resim 4. Fatih Sultan Mehmed Hocası Molla Gürani'nin Huzurunda _................................................. 44

REsim 5. Tıraz ve Sarık Giymiș İki Öğrenci ................................................................................................. 56

RESim 6. Ders Anlatan Hoca _..................................................................................................................... 57

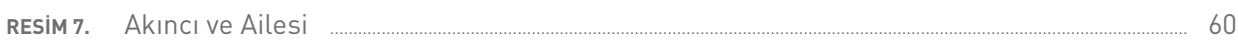

Resim 8. Bir Geçit Resmi Esnasında Ulema _....................................................................................... 71

REsim 9. Yüksek Kadılar ile Kadıaskerlerin Ziyafeti; Șenliğin 2. Günü _.............................................. 75

REsim 10. 3. Murad'ın Oğlu 3. Mehmed'in Sünnet Töreninde Yeniçeriler Ağalara Hil'at Giydirirken ................................................................................................................. 81

REsim 11. Müderris Ahmed Karabaği ile Nakkaș ve Katipler ................................................................................. 83

REsim 12. İstanbul Rasathanesi'nde Gözlem Yapan Astronomlar ...................................................................... 87

REsim 13. Osmanlı Devlet Ricalinden Sol Üstte Șeyhülislam ile Sağ Üstte Nakibüleșraf Efendi ...... 91

REsim 14. 3. Murad'ın Oğlu 3. Mehmed'in Sünnet Töreninde Geçit Resmi Yapan Nemed Destarcılar ………....................................................................... 99

REsim 15. 3. Murad'ın Oğlu 3. Mehmed'in Sünnet Töreninde Geçit Resmi Yapan Takkeciler ............ 103

REsim 16. 3. Murad'ın Oğlu 3. Mehmed'in Sünnet Töreninde Geçit Resmi Yapan Sarıkçılar ............... 107

REsim 17. 3. Murad'ın Oğlu 3. Mehmed'in Sünnet Töreninde Geçit Resmi Yapan Terziler .................... 117

REsim 18. 3. Murad'ın Oğlu 3. Mehmed'in Sünnet Töreninde Geçit Resmi Yapan Kaftancılar ........... 121 
REsim 19. 3. Murad'ın Oğlu 3. Mehmed'in Sünnet Töreninde Geçit Resmi Yapan Kürkçüler

REsim 20. 3. Murad'ın Oğlu 3. Mehmed'in Sünnet Töreninde Geçit Resmi Yapan C̦akșırcılar

REsim 21. 3. Murad'ın Oğlu 3. Mehmed'in Sünnet Töreninde Geçit Resmi Yapan Kușakçılar

REsim 22. 3. Murad'ın Oğlu 3. Mehmed'in Sünnet Töreninde Geçit Resmi Yapan Peștamalciler

REsim 23. 3. Murad'ın Oğlu 3. Mehmed'in Sünnet Töreninde Geçit Resmi Yapan Çedik ve Mestçiler

REsim 24. 3. Murad'ın Oğlu 3. Mehmed'in Sünnet Töreninde Geçit Resmi Yapan Pabuççular

RESim 25. 3. Murad'ın Oğlu 3. Mehmed'in Sünnet Töreninde Geçit Resmi Yapan Çizmeciler 149

RESim 26. Ebussud Efendi Ders Anlatırken 152

REsim 27. Okulun İlk Günü [De Eerste Schooldag]

REsim 28. 3. Murad'ın Oğlu 3. Mehmed'in Sünnet Töreninde Geçit Resmi Yapan Suhtegan-ı Anadolu

REsim 29. 3. Murad'ın Oğlu 3. Mehmed'in Sünnet Töreninde Geçit Resmi Yapan Danișmentler ..... 163

REsim 30. 3. Murad’ın Oğlu 3. Mehmed'in Sünnet Töreninde Geçit Resmi Yapan Danișmentler ..... 169

RESim 31. Leyla ile Mecnun Sınıfta 171

REsim 32. Molla Hasan Pașa'nın Huzurunda Dersini Okuyan Bir Öğrenci

Resim 33. Gazanfer Ağa Medresesi'nde Bir Ders

REsim 34. Gazanfer Ağa Medresesi'nin Açılıșı 176

REsim 35. Molla Kara Yakup ile Öğrencisi

REsim 36. Molla Muslihuddin Mustafa Ders Anlatırken 178

REsim 37. Çak Muslihuddin Ders Esnasında 181

REsim 38. Bir Grup Darülmuallimin Öğrencisi 182

REsiм 39. Darülmuallimin-i İbtidaiye Kısmı Șakirdanı 183

REsim 40. Bir Öğrenci Grubu 184

RESim 41. Darülmuallimin-i İbtidaiye ve Rüșdiyesi Șakirdanı 186

REsim 42. 3. Murad'ın Oğlu 3. Mehmed'in Sünnet Töreninde Geçit Resmi Yapan Mazul Kadılar

REsim 43. Yıldırım Bayezid ile Molla Fenari

Resim 44. Molla Balat Kadısı Bir Mesele Hakkında Görüșürken

REsim 45. 3. Murad'ın Oğlu 3. Mehmed'in Sünnet Töreninde Geçit Resmi Yapan Hatipler

REsim 46. Müftü [Mufti Patriarchate et Grand Interprète de l'Alforcan]

RESiM 47. Müftü

REsim 48. Beșinci Alay’ın Müftüsü Ali Osman Efendi

RESiM 49. Müftü

Resim 50. Molla Arap

REsim 51. Kıraat Âlimi Șeyh Ebülhayr Muhammed el-Cezeri Bir Eseri İncelerken

REsim 52. Molla Ubeydullah Bir Eseri Tetkik Ederken

REsim 53. Molla Ali Çelebi Bir Öğrencisine Ders Anlatırken 


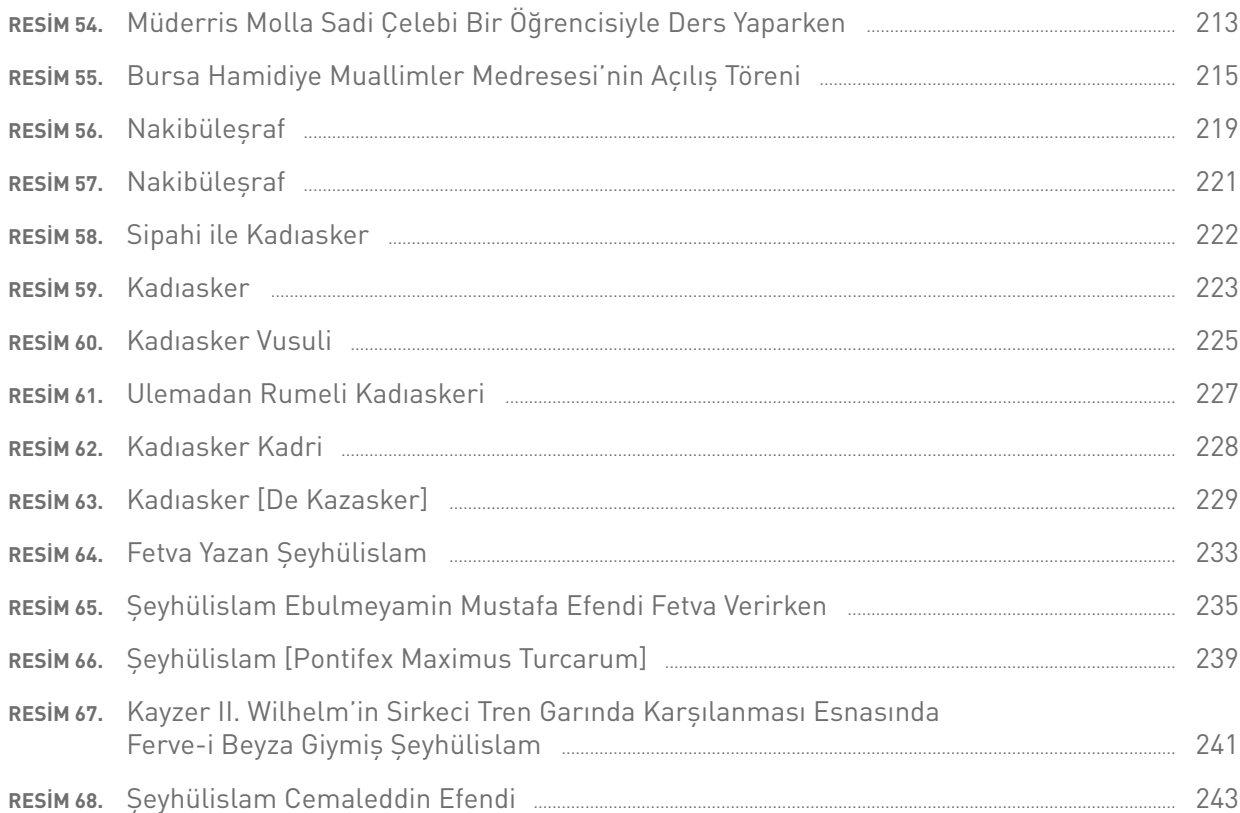

\section{BELGELER}

BELGE 1. Divan'dan Verilen Hil'at, Giyim ve İnamatı Gösteren 1650 Tarihli Defter Kaydı 68

BELGE 2. Divan'dan Verilen Hil'at, Giyim ve İnamatı Gösteren 1650 Tarihli Defter Kaydı

BELGE 3. Takyeci Mahallesi İmam Vekili ve Kassam-ı Askerî Kalemi Müdavimlerinden Hafız Mustafa Efendi'nin Üzerinde Ulema Giysisi İle Bira İçerken Görülmesi Hakkında 1900 Tarihli Belge

BELGE 4. Sultan, Șeyhülislam, Șehzadeler ve Diğer Kimseler İçin Yaptırılan Entari, Kürk Kabı, Ferace, Mintan, Kontoș, İclik ve Cübbelerin 1788 Tarihli Müfredat ve Hesap Defteri.

BELGE 5. Sultan, Șeyhülislam, Șehzadeler ve Diğer Kimseler İçin Yaptırılan Entari, Kürk Kabı, Ferace, Mintan, Kontoș, İçlik ve Cübbelerin 1788 Tarihli Müfredat ve Hesap Defteri ...... 113

BELGE 6. Her Yıl Bayramlarda Verilmesi Gelenek Olan Medrese Öğrencilerine İhsan Buyurulacak Elbise Bedellerinin Ödenmesi Hakkında 1727 Tarihli Belge

BELGE 7. Șeyhülislama, Danișmentlere, Șeyhülislam Telhiscisine ve Nakibüleșrafa Gönderilen Yazlık Melbusat Kumașları Hakkındaki 1780 Tarihli Müfredat Defteri

BELGE 8. Suhte Kıyafetiyle Pire'ye gelerek Dersaadet'e Gitmek Üzere Vapura Binen Mardrosyan Adlı Șahsa İlișkin 1897 Tarihli Belge

BELGE 9. Șeyhülislama Mesned-nișin-i Meșihat Olduklarından Ötürü İlbas Olunan Hil'atın Satın Alınmasına İlișkin 1716 Tarihli Buyruldu

BELGE 10. Kurban Bayramı'nda Sultanın Huzurunda Șeyhülislama Giydirilmek Üzere Alınması İstenen Hil'ate Ait Makbuz 


\section{Kisaltmalar}

$\begin{array}{ll}\text { a } & \text { A yüzü } \\ \text { b } & \text { B yüzü } \\ \text { bsm. } & \text { Basım } \\ \text { cm } & \text { Santimetre } \\ \text { çev. } & \text { Çeviren } \\ \text { Ed. } & \text { Edisyon } \\ \text { ed. } & \text { Editör } \\ \text { fol. } & \text { Folio } \\ \text { haz. } & \text { Hazırlayan } \\ \text { nşr. } & \text { Neşreden } \\ \text { İ̈KK } & \text { İstanbul Üniversitesi Nadir Eserler Kütüphanesi } \\ \text { ö. } & \text { Ölüm Tarihi } \\ \text { r. } & \text { Recto } \\ \text { sad. } & \text { Sadeleştiren } \\ \text { t. } & \text { Tesis Tarihi } \\ \text { trc. } & \text { Tercüme }\end{array}$

TSMK Topkapı Sarayı Müzesi Kütüphanesi

t.y. Tarihi Yok

v. Verso

v. dğr. Ve Diğerleri

y.y. Yayıncisı Yok/Yayın Yeri Yok

yay. haz. Yayına Hazırlayan 


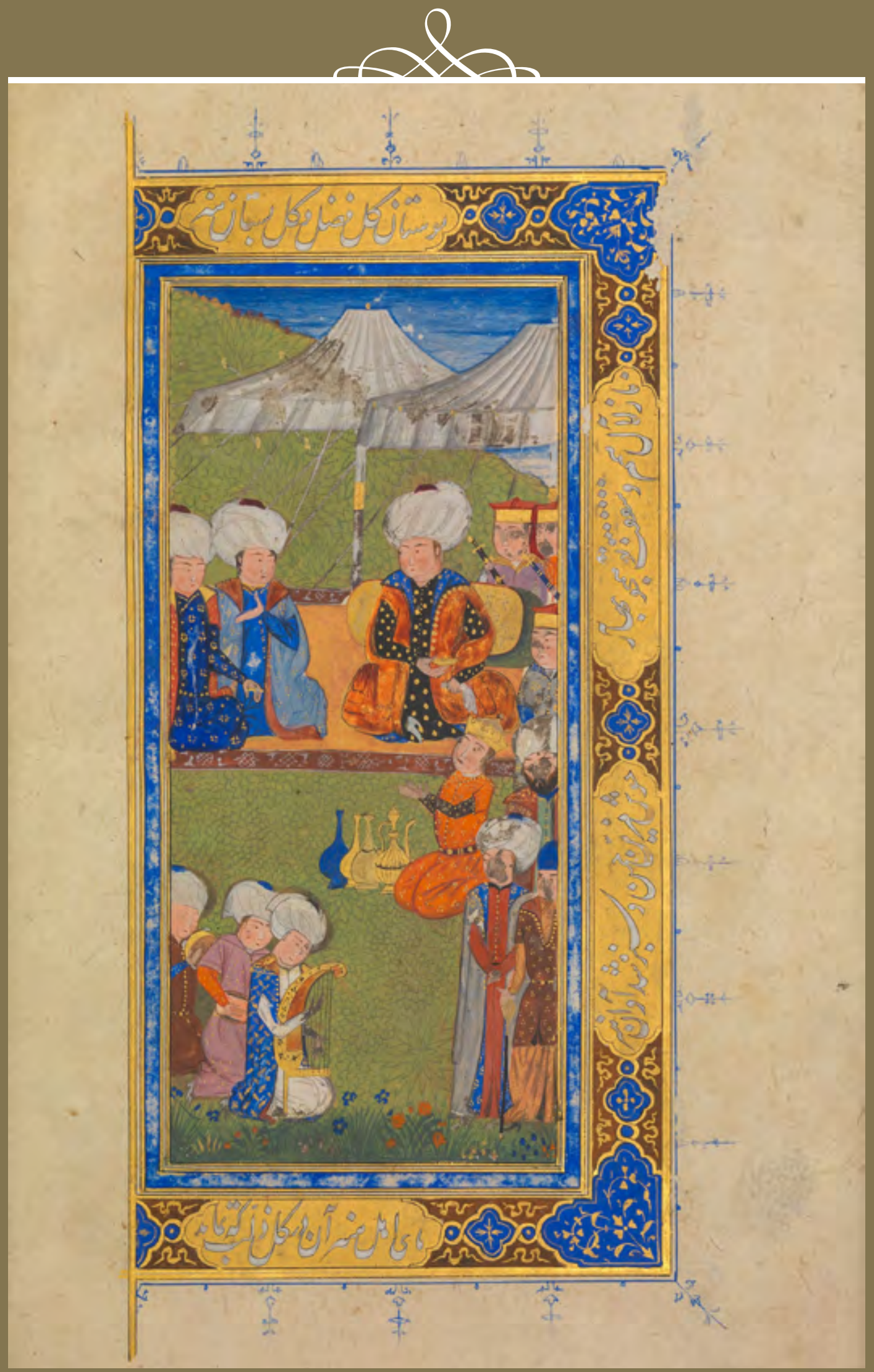

RESiM 3. Șiir Meclisi

Hatifi, Hüsrev ü Șirin, New York Metropolitan Sanat Müzesi [The Metropolitan Museum of Art], N. 69.27, 1v. 


\section{Giriș}

Giyimin toplumsal bakımdan salt fiziki örtünme ihtiyacından daha başka gerekçeleri de bulunur. Çünkü giyim fiziki koşullar yanında konum, sınıf ve grup ilişkilerinin belirlenmesinin temelinde de yer alır. ${ }^{1}$ Dolayısıyla giyim söz konusu olduğunda somut varlığından ziyade soyut ve etkilediği toplumsal mekanizmalar akla gelir. Kıyafetin diğer pek çok alan yanında ekonomik ve sosyal içeriği ile antropolojik bir hal alması, işaret edilen bu mekanizmalardan kaynaklanır. Giyimin böylesine önemli bir etken olmasının altındaysa, ahlaki ve politik olmak üzere iki içkin değere sahip bulunması yatar. ${ }^{2}$ Kuşkusuz aksesuar gibi diğer ekleriyle birlikte ele alındığında giyim, bir güç aktarımı ya da gösterisi olması bakımından sembolik, yapısal ve semiyotik derinlikleriyle de entelektüel zihni meşgul eder. ${ }^{3}$ Uzaktan bakınca, aslında, giyim üzerinden üretilenin kimlikler olduğu ifade edilebilir.

Quentin Bell, Of Human Finery (London: Hogarth Press, 1947), 9.

2 Elisabeth Wilson ve Amy de la Haye, "Introduction," Defining Dress: Dress and Object, Meaning and Identity içinde, ed. Elisabeth Wilson ve Amy de la Haye, (Manchester, New York: Manchester University Press, 1999), 2.

3 Karen Tranberg Hansen, "The World in Dress: Antropological Perspectives on Clothing, Fashion, and Culture," Annual Review of Anthropology I, 33 (2004): 370. 
Çünkü akademik bir anlayıştan ziyade pratik amaçlarla uygulanan tasnif kendisini en açık biçimde, ancak, kıyafet ile gösterebilecektir. Bu alana dair önemli çalışmalar yapılmış, kıyafet ile toplum arasındaki ilişkilerin ortaya konduğu değerli bir literatür meydana getirilmiştir. ${ }^{4}$

Giyimin en görünür olduğu ya da bir araç olarak kullanıldığı alan kuşkusuz eğitim ve onun entelektüel yapısıdır. Temel bileşenlerinden biri olarak sınıflandırmanın tam da burada, eğitimde, yaygın bir uygulama alanı bulduğu ifade edilebilir. Ancak bu sınıflandırmanın alan bulduğu zemin ise cinsiyet, yaş ve iş yaşamındaki rollerin giyimin sosyal farklılaşma ve tabakalaşmada aldığı konumdur. Son tahlilde giyim ve onun sinıflama becerisinin toplumsal hiyerarşinin ustaca tasarlanmış bir aracı olduğu söylenebilir. ${ }^{5} \mathrm{Bu}$ yüzden toplumsal etkilerin dışında kurumsal etkilerin de göz ardı edilmemesi gerekir. Çünkü böylelikle birey üzerinden kurumsal düzenleme, kurumsal düzenleme üzerinden de bireysel kontrol sağlanabilmektedir. ${ }^{6}$

Yukarıdaki ifadeden kaynaklı bir şekilde giyim ve eğitimin bir araya geldiği noktanın, kurumsal düzenleme ve bireysel kontrolün sağlandığı yer olduğuna işaret edilmelidir. Keza, kıyafetin bir düzenleme işlevinin olması

4 Bazı çalışmalar için bakınız: Nathan Joseph ve Nicholas Alex, "The Uniform: A Sociological Perspective," American fournal of Sociology LXXVII, 4, (1972): 719-730. L. Brickman, "The Social Power of A Uniform," Fournal Social Psychology IV, (1974): 47-61. Barbara Hunt Conner v. dğr.. "Person and Costume: Effects on the Formation of First Impression," Home Economics Research fournal IV, 1 (1975): 32-41. Alison Lurie, The Language of Clothes (New York: Random House, 1981). Paul Fussell, Class: A Guide Through the American Status System (New York: Ballantine Books, 1983). Nathan Joseph, Uniforms and Nonuniforms: Communication Through Clothing (New York: Greenwoods Press, 1986). Ruth Barnes ve Joanne B. Eicher, Dress and Gender: Making and Meaning (Oxford: Berg Publishers, 1992). Anna B. Eicher, "The Anthropology of Dress," Dress 27, (2000): 59-70. Anna Brydon ve Sandra Niessen, Consuming Faxhion: Adorning the Transnational Body (Oxford: Berg Publishers, 1998). Linda B. Arthur (ed.), Religion Dress and Body (Oxford: Berg Publishers, 1999).

5 Hilda Kuper, "Costume and Identity," Comparative Studies in Society and History XV, 3 (1973): 350, 353.

6 Linda B. Arthur, "Introduction: Dress and the Social Control of the Body," Religion, Dress and the Body içinde, ed. Linda B. Arthur (Oxford, New York: Berg, 2000), 3. 
yanında eğitimin sınıfsal tabakalaşmaya yol açması da sosyal ilişkilerin giyimi somut bir araca dönüştürmesine neden olmuştur. Bu bakımdan giyim ile eğitimin yakından incelenmesi bir gereklilik halini almıştır. Kaldı ki, 20. yüzyılın ikinci yarısının eğitim tarihi, bilhassa yükseköğrenim tarihinin gelişim gösterdiği zaman dilimi olduğu hatırlanmalıdır. Bu çerçevede ilkin Avrupa'da başlayan üniversite tarihine yönelik ilgi diğer entelektüel ortamları da etkisi altına almış ve bugüne dek zengin bir literatür meydana getirilmiştir. Söz konusu literatür yükseköğrenimin ders programları, işleyiş ve finansal alanlar başta olmak üzere hemen pek çok konusunu kapsama alanına dahil etmiştir. Dahil edilen bu konulardan önemli bir bölümünü üniversite eğitiminde kullanılan giysi ve kıyafet düzenlemeleri meydana getirmektedir. Bununla beraber eğer Avrupa'daki zengin literatürle mukayese edilecek olursa Osmanlı yükseköğrenimine ilişkin çalışmaların o ölçüde olmadığı dile getirilebilir. Kuşkusuz Osmanlı eğitim tarihinin kıyafet bölümü de bu çerçevede, ayrıca ve ayrıntılı bir biçimde henüz yeterince ele alınmamıştır. Oysa Osmanlı medrese tarihi çalışmalarının okunan kitaplar, müderris biyografileri, medrese mimarisi ve benzer konularının dışında önemli bir parçası olarak kıyafet araştırmalarının gelişim göstermesi de beklenirdi. Çünkü Osmanlı medreselerinin bir ürünü olan ilmiye sinıfi kıyafetlerinin hem pedagojik hem tarih hem sosyolojik hem de antropolojik arka planlarından söz edilmesi mümkünken bu alanın gelişmemiş olması ilgi çekicidir. Bu yüzden kıyafetlerinin tartışılmaya başlanmasıyla Osmanlı ilmiye sınıfının daha iyi anlaşılmasına imkan sağlayacağı aşikardır. Zira giyimin Osmanlı ilmiyesi özelinden yola çıkarak toplumsal bir biçimde anlam yüküne sahip olduğu gerçeği göz ardı edilemez. Öyle ki, giyimin hem kurum dışında sahip bulunduğu toplumsal ve kurumsal düzenlemeleri hem de kurum içinde bir değer ve yapı kurucu olması son derece mühimdir. ${ }^{7}$ Her iki ana

Anat Rafaeli ve Michael G. Pratt, "Tailored Meanings: On the Meaning and Impact of Organizational Dress," The Academy of Management Revieres XVIII, 1 (1993): 33. 
damar da bir bakıma kurumsal açıklık ve belirginliği ortaya koymaktadır. Diğer bir deyişle, giyim aslında yukarıda ifade edilen düzenler kurulurken iş yapma biçimleri ile taşınılan değerleri de hukuki bir düzleme kavuşturmaktadır.

Son tahlilde her kültür ve toplumda olduğu gibi Osmanlı toplumunda da cemiyete ait yazılı olan ve olmayan kurallar meydana getirilmiştir. Bahsi edilen bu kuralların başında da giyim kuşama ait olanlar gelmektedir. Zamanla toplumun farklı tabakaları için farklı giyim kuralları oluşmuştur. Kurallar ise kişilerin, meslek gruplarının yahut toplumsal sınıfların konumu, diğerleri ile ilişki ve iş yapma biçimleri çerçevesinde teşekkül etmiştir. Mesela Osmanlı toplumunda cübbe, ekseriyetle ilmiye mensupları tarafindan benimsenerek bir süre sonra ilmiyeyi oluşturan grupların alametifarikası haline dönüşmüştür. Çünkü kaçırılmaması gereken ipucu ilmiyeye ait giyimlerin renk, malzeme ve biçimlerle onlara has bir kimliği oluşturmasıdır. Üçlü altyapı bir bakıma ilmiyenin kurumsal kimliğini şekillendirmiştir. Böylece renk ve malzemelerle birlikte yazılı olmayan bir düzen, dahası son derece değerli bir sembolik dil icat edilmiştir. ${ }^{8}$

İlmiyenin bir kıyafetle ayrışmaya gitmesinin arka planında ise merak uyandırıcı bir Osmanlı düzen mekanizması yatmaktadır. Çünkü kıyafet düzenlemesine tabi olan kimselerin 'askerî sınıfi' meydana getirmeleri son derece dikkat çekicidir. Zaten askerî sınıf meselesi ilmiye mensuplarından farklı olarak kıyafet normunun anlaşılmasının merkezinde yer almaktadır. Çünkü kıyafet ya da üniforma niteliğindeki giyim, bir şekilde sultanın kullarının reayadan ayrılması anlamına gelmektedir. Uzaktan bakıldığında kıyafet düzenlemesi üzerinden böylesi bir farklılığın sağlanması son derece pratik bir davranış biçimi sayılabilir. Bu yüzden askerî sınıf tanımlaması tam da burada önem arz etmektedir. Nedir askerî sınıf? Askerî sınıf tanımı Barkan'dan nakledilecek olursa, "Fïli olarak hizmette bulunan hakiki askerler ile bunlarn çocuklan, karları ve azat edilmiş köleleri yannda emeklileri; müderris, imam,

8 Rafaeli, "Tailored Meanings: On the Meaning and Impact of Organizational Dress," 35 . 
müezzin, vakif hademesi... gibi vazifelerine bir padişah beratn ile tayin edilmiş olan her çeşit maaşh memur ve hizmetliler ile sultanlar tarafindan ellerine vergilerden affedildiklerine dair mu'afiyetname verilmiş olan bazı imtiyazh kişiler ve tuzcu, ortakç, madenci ve ilh.. gibi bir hizmet mukabili fevkalade tekalif'ten muaf tutulan zümreler..."dir." $\mathrm{Bu}$ tanımlamadan ayrı olarak ilmiye mensuplarının da diğger bölümler gibi olmasa da askerî sınıfin birer üyesi bulunmaları onların da kıyafet düzenlemelerinden paylarına birer hisse düşmesine yol açmıştır. Bu bakımdan ilmiye mensupları da askerî sınıfın birer üyesidirler ve sultanın sadık bendeleri ve kararlarının hukukileştiricileri olarak fevkalade bir konuma sahiptirler. Söz konusu bu üstün konum, klyafetlerle de pekiştirilerek görsel bir tanımlamaya ya da tasnife sebep olmuştur. Zaten Pakalın'ın da not ettiği üzere, "İlme mensup manasına gelen bu kelime istrlah olarak ulema tarafindan ihtiyar olunan kiyafette bulunanlar demektir. Bu tarzda givinişlere "ilmiye kuyafeti" denildiği gibi bu türlü giyinenlere "ilmiye mensubu" bu mensubinin yüksek tabakasina "ilmiye ricali" denilirdi. Bu kuyafeti ihtiyar eden imam ve hatip gibilerden medrese tahsili görmiyenler ilmiye mensubu saylmadiklan halde Meşihatte herhangi bir memuriyet alan ve başına sarkk sarı arkasına cübbe giyen ilmiye mensubu addolurdu."10 Bu yüzden diğer eğitim geleneklerinde olduğu gibi bir askerî sınıf olarak ulemanın da kendisine has bir kıyafeti, bu kıyafetin medreselileri reayadan ayrıcı bir işleyişi bulunması şaşırtıcı olmayan son derece gerçekçi ve faydacı bir Osmanlı uygulamasıdır.

Ömer Barkan, "Edirne Askerî Kassamı'na Ait Tereke Defterleri: (1545-1659)," Belgeler III, 5-6 (1966): 4.

10 Mehmet Zeki Pakalın, Osmanh Tarih Deyimleri ve Terimleri Sözlügü: 2, 3. bsm. (İstanbul: Milli Eğitim Bakanlı̆̆ı, 1983), 52-53. 


\section{Kaynakça}

\section{ARȘIV BELGELERi}

Cumhurbaşkanlı̆̆ı Devlet Arşivleri Başkanlığı

\section{Cumhuriyet Arşivi}

$51 / 12.99 .21$

\section{Osmanlı Arşivi}

A. \{DVNSMHM.d. 25/2602

A. \{DVNSMHM.d. 39/525

A. \}MKT.MHM. 542/29

AE.SAMD.III. 143/13831

AE.SAMD.III. 232/22216

AE:SMHD.I. 43/2573

AE.SMHD.I. 179/13968

AE.SMMD.IV. 45/5145

AE.SMMD.IV. 47/5334

AE.SMST.III. 84/6215

AE.SSÜL.I. 2/46

C.ADL. 29/1727

C.ADL. 81/4908

C.ADL. 104/6213 

C.ADL. 105/6294
C.DH. 343/17132
C.BH. 149/7122
C.ML. 28/1320
D.TŞF.d. 26020
D.TŞF.d. 26080
IE.HLT. $1 / 2$
IE.HLT. 3/301
IE.HLT. 5/460
KK.d. 664
KK.d. 682
ZB. $350 / 78$

\section{Topkapı Sarayı Müzesi Arşivi}
D. 2321
D. 2434
D. 5455

\section{ÖZGÜN KAYNAKLAR}

Âşık Çelebi. Meşairü’ş-şuara. Millet Kütüphanesi, Ali Emiri 772.

De Bruyn, Abraham Habitus variarum orbis gentium. Habitz de nations estranges. [Coloniae]: [Caspar Rütz], 1581.

Dobrudja Artistique: Darülmuallimin, 1901. IÜK II. Abdülhamid Han Fotoğraf Albümleri NEKYA91331/36.

Dürer, Albrecht. The Turkish Family. New York Metropolitan Sanat Müzesi [The Metropolitan Museum of Art], N. 19.73.97.

Dürer, Albrecht. Three Orientals, Three Turks Wearing Long Coats and Turbans. Britanya Müzesi [British Museum], 1895,0915.974.

Elbise-i Atika-i Osmaniye Risalesi. IÜK, T.9362.

Eski Osmanh Devlet Ricali Kiyafetleri. İ̈K, II. Abdülhamid Han Fotoğraf Albümleri NEKYBA90673/32.

Fréres, Abdullah. Darülmuallimin-i İbtidaiye Kısmı Şakirdanı. Amerika Birleşik Devletleri Kongre Kütüphanesi [The Library of Congress]. 2. Abdülhamid Koleksiyonu LG-USZ62-81501. 
Fréres, Abdullah. Darülmuallimin-i İbtidaiye ve Rüşdiyesi Şakirdanı. Amerika Birleşik Devletleri Kongre Kütüphanesi [The Library of Congress]. 2. Abdülhamid Koleksiyonu LC-USZ62-81502.

Gazanfer Ağa Mescidinin Küşadı Hakkında Manzume. Süleymaniye Yazma Eserler Kütüphanesi, Ayasofya 4787.

The Habits of the Grand Signor's Court. Britanya Müzesi [British Museum], $1928,0323,0.46$.

Hatifi. Hüsrev ü Şirin. New York Metropolitan Sanat Müzesi [The Metropolitan Museum of Art], N. 69.27.

Hendrowski, Heinrich. Bilder aus dem türkischen Volksleben. Avurturya Milli Kütüphanesi [Österreichische Nationalbibliothek], I Turchi. Codex Vindobonensis 8626.

Kitabü'l-Haşaiş [De Materia Medica]. TSMK, 3. Ahmet Kitaplı̆̆ı, 2127.

Ligozzi, Jacopo. Il Papa dei Turchi. Le Gallerie degli Uffizi, Gabinetto Disegni e Stampe 2953.

Magrin, A.. Dobrudja Artistique: Müftü. İÜK, II. Abdülhamid Han Fotoğraf Albümleri NEKYA91331/4.

Magrin, A.. Dobrudja Artistique: Darülmuallimin. İÜK, II. Abdülhamid Han Fotoğraf Albümleri NEKYA91331/36.

Mahmud Abdülbaki, Divan-ı Mahmud. New York Metropolitan Sanat Müzesi [The Metropolitan Museum of Art], N. 25.83.9.

Mehmed bin Abdülgani bin Emirşah. Divan-ı Nadiri. TSMK, Hazine 889.

Mehmed bin Mehmed el-Fenari [Talikizade Mehmed Subhi]. Firasetname. Fransa Milli Kütüphanesi [Bibliothèque Nationale de France], Supplément Turc 1055 .

Muhtesibzade Mehmed Belgradi. Tercüme-i Şakaiku'n-numaniyye. TSMK, Hazine 1263.

Mundy, Peter. A briefe relation of the Turckes, their kings, Emperors, or Grandsigneurs, their conquests, religion, customes, habbits, etc. Britanya Müzesi [British Museum], 1974,0617,0.13.16.

Nicolay, Nicolas de. Discours et Histoire Veritable des Navigations, Peregrinations et Voyages, Faicts en la Torquie. Anvers: A. Coninx, 1586. 
Nizami-i Gencevi. Leyla vü Mecnun. Süleymaniye Yazma Eserler Kütüphanesi, Ayasofya 3289.

Rålambska Dräktboken. İsveç Kraliyet Kütüphanesi [Kungliga biblioteket], Cod. Rål. 8:o nr. 10.

Raynal. Figures Naturelles de Turquie. 1688. Fransa Milli Kütüphanesi [Bibliothèque Nationale de France], IFN-8455919.

Rycaut, Paul. The History of The Present State of thev Ottoman Empire, Containing the Maxims of the Turkish Politie, the Most Material Points of the Mahometan religion. Their Sects and Heresies, Their Convents and Religious Votaries. Their Military Discipline, with an Exact Computation of Their Forces Both by Sea and Land. London: John Starkey \& Henry Brome, 1667.

Salute de Constantinople: Groupe de Softas. İstanbul Büyükşehir Belediyesi Atatürk Kitaplı̆̆ı, Kartpostal Arşivi 12833.

Schweigger, Salomon. Ein newe Reiss Beschreibung auss Teutschland nach Constantinopel und Ferusalem. Nürnberg: Gedruckt durch Christoff Lochner, Velegung Wolffgang Endters, 1639.

Selamlık Resm-i Âlîsine Memur Ümera ve Zabitan: Beşinci Alayın Müftüsü Ali Osman Efendi. İÜK, II. Abdülhamid Han Fotoğraf Albümleri NEKYA91301/31.

Seyyid Lokman bin Hüseyin el-Urmevi. Şehinşahname. IÜK, F.1404.

Seyyid Lokman bin Hüseyin el-Urmevi. Şehname-i Selim Han. TSMK, 3. Ahmet Kitaplığ1 3595.

Seyyid Vehbi Hüseyin bin Abdullah. Surname-i Vehbi. TSMK, 3. Ahmet Kitaplığı 3594.

The Sheikh ul Islam, Emperor Wilhelm II, the Sultan, Excellency Enver Pasha, WWI. Wikipedia Commons. 02 Şubat 2019'da erişildi. https://commons.wikimedia.org/wiki/File:The_sheikh_ul_Islam,_Emperor_Wilhelm_II,_the_sultan,_Excellency_Enver_Pasha,_WWI_(29411748075).jpg

Surname-i Hümayun. TSMK, Hazine 1344.

Turban. Schloss Ambras Innsbruck, WA 2818.

Vanmour, Jean Baptiste. De Eerste Schooldag. Rijks Müzesi [Rijksmuseum], SK-A2005.

Vanmour, Jean Baptiste. De Kazasker. Rijsks Müzesi [Rijksmuseum], SK-A-2022. 
Weigel, Hans. Habitus praecipuorum populorum tam virorum quam foeminarum sigulari arte depicti. Nuremberg: [y.y.], 1577.

Verona, Pavlo. Sultan Abdülmecid'in Kilıç Alayı. 14 Nisan 2019'da erişildi. www.artistwonders.com/milli-saraylar-resim-müzesi-birinci-kat/

\section{YAYIMLANMIS ÖZGÜN KAYNAKLAR}

5 Numaralı Mühimme Defteri: (973/1565-1566). Ankara: Başbakanlık Devlet Arşivleri Genel Müdürlüğü, 1994.

6 Numaralı Mühimme Defteri: (972/1564-1565): I. Ankara: Başbakanlık Devlet Arşivleri Genel Müdürlüğü, 1995.

7 Numarah Mühimme Defteri: (975-976/1567-1569): II. Ankara: Başbakanlık Devlet Arşivleri Genel Müdürlüğü, 1999.

7 Numarah Mühimme Defteri: (975-976/1567-1569): III. Ankara: Başbakanlık Devlet Arşivleri Genel Müdürlüğü, 1999.

Abdüllatif Çelebi, Latifi. Tezkiretü'ş-şu'arâ ve Tabstratü’n-nuzamâ: (İnceleme-Metin). Haz. Rıdvan Canım. Ankara: Atatürk Kültür Merkezi Başkanlığı, 2000.

Âşık Çelebi. Meşẩirü’ş-şu'arâ: Inceleme ve Metin: 1. Haz. Filiz Kılıç. İstanbul: İstanbul Araştırmaları Enstitüsü, 2010.

Atasoy, Nurhan. 1582: Surname-i Hümayun: Düğün Kitabı. İstanbul: Koç Bank, 1997.

Barkan, Ömer. "Edirne Askerî Kassamı'na Ait Tereke Defterleri: (1545-1659)." Belgeler III, 5-6 (1966): 1-479.

Barkan, Ömer Lütfü. "İstanbul Saraylarına Ait Muhasebe Defterleri." Belgeler IX, 13 (1979): 1-380.

Evliya Çelebi. Günümüz Türkçesiyle Evliya Çelebi Seyahatnamesi: İstanbul: 1. Cilt: 1-2. Kitap. 5. bsm.. Haz. Yücel Dağlı ve Ali Seyit Kahraman. İstanbul: Yapı Kredi Yayınları, 2008.

Gelibolulu Mustafa Âlî. Hâlâtü'l-Kahire mine'l-Âdâti'z-zâhire. Sad. Orhan Şaik Gökyay. Ankara: Kültür ve Turizm Bakanlığı, 1984.

Hüdavendigar Vilayeti Salname-i Resmisi: 1325. 34. Defa. Brusa: Matbaa-i Vilayet, 1325.

İbn Battuta Tanci, Ebu Abdullah Muhammed. Ibn Battuta Seyahatnamesi: 1. 2. bsm., Çev. A. Sait Aykut. İstanbul: Yapı Kredi yayınları, 2004. 
Istanbul Kadı Sicilleri Bab Mahkemesi 3 Numarah Sicil (H. 1077 / M. 1666 - 1667) 17. İstanbul: Türkiye Diyanet Vakfi İslam Araştırmaları Merkezi, 2011.

Istanbul Kadı Sicilleri Bab Mahkemesi 150 Numarah Sicil (H. 1102/M. 1691) 65. İstanbul: Kültür A. Ş. 2019.

Istanbul Kadı Sicilleri Eyüb Mahkemesi (Havass-ı Refia) 74 Numarah Sicil (H. 1072 - 1073 / M. 1661 - 1662) 28. İstanbul: Türkiye Diyanet Vakfi İslam Araştırmaları Merkezi, 2011.

Istanbul Kadı Sicilleri Eyüp Mahkemesi 163 Numarah Sicil (H. 1147-1149 / M. 17341736) 67. İstanbul: Kültür A. Ş., 2019.

Istanbul Kadn Sicilleri Istanbul Mahkemesi 10 Numarah Sicil (H. 1072-1073 / M. 16611663) 51. İstanbul: Kültür A. Ş., 2019.

Ístanbul Kadr Sicilleri İstanbul Mahkemesi 22 Numarah Sicil (H. 1107-1108 / M. 16951697) 57. İstanbul: Kültür A. Ş., 2019.

Ístanbul Kadr Sicilleri İstanbul Mahkemesi 25 Numarah Sicil (H. 1179-1180 / M. 17651767) 76. İstanbul: Kültür A. Ş., 2019.

Ístanbul Kadı Sicilleri İstanbul Mahkemesi 97 Numarah Sicil (H.1217-1225 / M. 18021810) 83. İstanbul: Kültür A. Ş., 2019.

Ístanbul Kadı Sicilleri İstanbul Mahkemesi 154 Numarah Sicil (H. 1237-1246 / M. 1822 1831), 88. İstanbul: Kültür A. Ş., 2019.

Istanbul Kadı Sicilleri Kismet-i Askeriye Mahkemesi 19 Numarah Sicil (H. 1109-1110 / M. 1698-1699) 58. İstanbul: Kültür A. Ş., 2019.

Istanbul Kadı Sicilleri Rumeli Sadareti Mahkemesi 21 Numarah Sicil (H. 1002-1003/M. 1594-1595) 12. İstanbul: Türkiye Diyanet Vakfi İslam Araştırmaları Merkezi, 2011.

Istanbul Kadı Sicilleri Rumeli Sadareti Mahkemesi 40 Numarah Sicil (H. 1033-1034 / M. 1623-1624) 46. İstanbul: Kültür A. Ş., 2019.

"Kanunname-i Âl-i Osman." Tarih-i Osmani Encümeni Mecmuası, [Ilave], 1329.

Mecdi Mehmed Efendi. Hadaikü’şşsakaik. Nşr. Abdülkadir Özcan. İstanbul: Çağrı Yayınları, 1989.

Naima Mustafa Efendi, Naîmâ Tarihi: 1. Çev. Zuhuri Danışman. İstanbul: Zuhuri Danışman Yayınevi, 1967.

Naima Mustafa Efendi, Naîmâ Tarihi: 4. Çev. Zuhuri Danışman (İstanbul: Zuhuri Danışman Yayınevi, 1968. 
Naima Mustafa Efendi, Nâ̂mâ Tarihi: 5. Çev. Zuhuri Danışman. İstanbul: Zuhuri Danışman Yayınevi, 1969.

İsen, Mustafa. Künhü'l-ahbâr'n Tezkire Kismı. Ankara: Atatürk Kültür, Dil ve Tarih Yüksek Kurumu 1994.

“Osmanlı Kanunnameleri." Milli Tetebbular Mecmuası I, 3 (1331): 497-544. [Tevkii Abdurrahman Paşa Kanunnamesi].

\section{ARASTTIRMA ESERLERI}

A Janissary's Headgear and Footwear. 10 Şubat 2019'da erişildi. http://www.kismeta. com/diGrasse/JanissaryHeadgear.htm\#Head

Abdülaziz Bey. Osmanh Adet, Merasim ve Tabirleri: Adat ve Merasim-i Kadime, Tabirat ve Muamelat-ı Kavmiye-i Osmaniye. Yay. Haz. Kazım Arısan, Duygu Arısan Günay. İstanbul: Türkiye Ekonomik ve Toplumsal Tarih Vakfi, 1995.

Aflalo, F. G.. Regilding the Crescent. London: Martin Secker, 1911.

Ahsan, Muhammad Manazir. "Social Life Under The Abbasids." Doktora Tezi, Londra Üniversitesi, 1973.

Akdağ, Mustafa. Celâli İsyanlar: (1550-1603). Ankara: Ankara Üniversitesi Dil-Tarih ve Coğrafya Fakültesi Yayınları 1963.

Akyüz, Jülide. "Osmanlı Ulemasından Üç Efendi’nin Terekeleri.” Akademik Araştrrmalar Dergisi 36, (2008): 188-200.

Alan, Ercan. "Yeni Bir Belgeye Göre Bursa Müderrislerinin Gelirleri." Iğdır Üniversitesi Sosyal Bilimler Dergisi, 16 (2018): 209-226.

Arif Mehmed Paşa, Mecmua-i Tesavir-i Osmaniye: Osmanl Imparatorluğu'nda Makamlar ve Kiyafetler. İstanbul: Galatasaray Holding, 1999.

Arthur, Linda B.. "Introduction: Dress and the Social Control of the Body." Religion, Dress and the Body içinde, ed. Linda B. Arthur, 1-7. Oxford, New York: Berg 2000.

Aslan, Ali. “18. Yüzyıl İstanbul İlim Hayatından Bir Kesit: Sıdkî Mustafa Efendi’nin Günlüğü ve Mülazemet Yılları.” Yüksek Lisans Tezi, İstanbul: İstanbul, 2015 .

Atasoy, Nurhan. "Selçuklu Kiyafetleri Üzerine Bir Deneme.” Sanat Tarihi Yillı̆̆ 4, (1971): 111-151. 
Aydın, Bilgin. "Edirne Tereke Sicilleri." Uluslararası Sempozyum: "Balkan Ülkeleri Arşiv Kaynaklarnda Edirne": 21-23 Ekim 2010, Edirne-Türkiye içinde, Yay. Haz. Tuba Karatepe, Bahattin Demirelli, 176-183. Edirne: Trakya Üniversitesi Rektörlüğ̈̈, 2010.

Ayhan, Fatma. "Türklerin Giyim Kuşamında Kürk.” 189-202, 09 Kasım 2018'de erişildi, http://www.ayk.gov.tr/wp-content/uploads/2015/01/AYHAN-Fatma-T\%C3\%9CRKLER $\%$ C4 $\%$ B0N-G\%C4\%B0Y\%C4\%B0M-KU\% C5\%9EAMINDA-K\%C3\%9CRK.pdf

Baker, Patricia L.. Islamic Textile. London: British Museum, 1995.

Baker, Patricia L.."Middle East: History of Islamic Dress: Dress in the Ottoman Empire." Encyclopedia of Clothing and Fashion: 2 içinde, ed. Valerie Steele, 402409. Detroit: Thomson Gale, 2005.

Baker, Patricia L.. "Islamic Honorific Garments." Costume 25, 1 (2013): 25-35.

Bozkurt, Nebi. "Nedim." Türkiye Diyanet Vakfi Íslam Ansiklopedisi XXXII, 509-510. Ankara: Türkiye Diyanet Vakfi, 2006.

Björkman, W.. "Sarık." İslâm Ansiklopedisi X, 221-233. İstanbul: Milli Eğitim Bakanlı̆̆ı, 1988.

Brindesi, Jean (Giovanni). Elbise-i Atîka: Elbice-i Atika: (Musée des Anciens Costumes Turcs de Constantinople): Osmanl Kiyafetleri. Haz. H. Ahmet Arslantürk ve M. Mert Sunar. İstanbul: Metamorfoz Yayıncılık, 2013.

Cenkmen, Emin. Osmanl Sarayı ve Kiyafetleri. İstanbul: Türkiye Yayınevi, 1948.

Gikar, Jutta. Türkischer Biographischer Index. Berlin: Walter de Gruyter, 2011.

Cosman, Madeleine Pelner ve Jones Linda G.. Handbook to Life in the Medieval World. New York: Facts on File, 2008.

Çelebi, Ahmet. "İslâm Eğitim-Öğretim Târihinde Müderrislerin Kıyafetleri." [çev.] Ali Yardım. Fikir ve Sanatta Hareket 6, 113 (1976): 42-45.

Çelebi, Ahmed. İslamda Eğitim-Öğretim Tarihi. Trc. Ali Yardım. İstanbul: Damla Yayınevi [t.y.].

Çetin, Ökkeş Hakan. “On Yedinci Yüzyıl Kıyafet Albümlerinde Osmanlı Erkek Giyim-Kuşamı.” The Fournal of Academic Social Sciences Studies 53, II (2016): 259264.

Çubukçu, Asri. "Muiz-lidinillâh." Türkiye Diyanet Vakfi İlam Ansiklopedisi XXXI, 95-97. Ankara: Türkiye Diyanet Vakfi, 2006. 
Dalvimart, Octavien ve Alexander, William. The Costume of Turkey. London: William Miller, 1804.

Dolanmaz, Hamide. "Osmanlı Cemiyetinde Elbise Nizamları Hakkında Bir Araştırma (XVI-XVII. Yüzyıl.” Lisans Tezi, İstanbul Üniversitesi, 1974.

Elliot, Matthew. "Dress Codes in the Ottoman Empire: The Case of the Franks." Ottoman Costumes: Frorm Textile to Identity içinde, ed. Suraiya Faroqhi ve Christopher K. Neumann, 103-123. İstanbul: Eren Yayıncılık, 2004.

Erbay, Halil İbrahim. "Teaching and Learning in the Madrasas of Istanbul During the Late Ottoman Period.” Doktora Tezi, Londra Üniversitesi, 2009.

Ercan, Yavuz. "Osmanlı İmparatorluğunda Gayrimüslimlerin Giyim, Mesken ve Davranış Hukuku." Ankara Üniversitesi Osmanh Tarihi Araştırma ve Uygulama Merkezi Dergisi, 1 (1990): 117-125.

Ergin, Osman Nuri. Türkiye Maarif Tarihi I-II. İstanbul: Eser Neşriyat, 1977.

Esad Efendi. Osmanlılarda Töre ve Törenler: [Teşrifât-ı Kadîme]. Sad. Yavuz Ercan, İstanbul: Tercüman Gazetesi, 1979.

Fekete, Lajos. "XVI. Yüzyılda Taşralı Bir Türk Efendi Evi.” çev. M. Tayyip Gökbilgin, Belleten XLIII, 170 (1979): 457-480.

Feyzioğlu, Hamiyet Sezer ve Kılıç, Selda. "Tanzimat Arifesinde Kadılık-Naiplik Kurumu." Ankara Üniversitesi Dil ve Tarih-Coğrafya Fakültesi Tarih Araștırmalar Dergisi 38, (2005): 1-23.

"Garment Lengths in 1624." 22 Mayıs 2019 tarihinde erişildi. http://www. issendai.com/16thcenturyistanbul/fabrics-and-colors/garment-lengths-in-the-1624-narh-defterleri/

Gatine, Georges Jacques. Costumes Orientaux Inédits, Dessinés d'Après Nature en 1796, 1797, 1798, 1802 et 1808, Gravés à l'eau-forte: Avec des Explications. Paris: y.y., 1813.

Goodwin, James. Eski Türk Kiyafetleri ve Giyim Tarzlar: Pictureque Representations of Dress and Manners of the Turks. Trc. Muharrem Feyzi. Istanbul: Zaman Kitaphanesi, 1932-1933.

Gök, İlhan. "Atatürk Kitaplığı M.C. O.71 Numaralı 909-933/1503-1527 Tarihli İn'âmât Defteri (Transkripsiyon-Değerlendirme)." Doktora Tezi, Marmara Üniversitesi, 2014. 
Görünür, Lâle. Pabuç: Sadberk Hanım Müzesi Koleksiyonundan. 2. bsm.. İstanbul: Sadberk Hanım Müzesi, Vehbi Koç Vakfi, 2016.

Görünür, Lale ve Ögel, Semra. "Osmanlı Kaftanları ile Entarilerinin Farkları ve Kullanılışları.” ITÜ Dergisi/b-Sosyal Bilimler III, 1 (2006): 59-68.

Güngör, Haydar. "Hz. Peygamber (S.A.S.) Döneminde Kullanılan Kiyafetler." Abant İzzet Baysal Üniversitesi İlahiyat Fakültesi Dergisi IV, 8 (2016): 48-68.

Hafiz Eşref Efendizade Şevketi. Medaris-i İslamiyye Islahat Programı. İstanbul: Hürriyet Matbaası, 1329.

Hansen, Karen Tranberg. "The World in Dress: Antropological Perspectives on Clothing, Fashion, and Culture." Annual Review of Anthropology I, 33, (2004): 369-392.

Hızlı, Mefail. Mahkeme Sicillerine Göre Osmanh Klasik Dönemi Bursa Medreselerinde Eğitim-Ögrretim. 2. bsm.. Bursa: Emin Yayınları, 2012.

Hızlı, Mefail. "Osmanlı Dönemi Bursa’sında Eğitim-Öğretim Vakıflarına Genel Bir Bakış.” Uludağ Üniversitesi Illahiyat Fakültesi Dergisi 7, 7 (1996): 183-191.

Hızlı, Mefail. "Osmanlı Sıbyan Mektepleri." Osmanlı: 5, ed. Güler Eren, 207217. Ankara: Yeni Türkiye Yayınları, 1999.

Hüseyin Kazım Kadri, Türk Lugati: 1. İstanbul: Milli Eğitim Basımevi, 1928.

İlgürel, Mücteba. "Acemi Oğlanı." Türkiye Diyanet Vakfi İslam Ansiklopedisi I, 324325. Ankara: Türkiye Diyanet Vakfı, 1998.

İnalcık, Halil. Türkiye Tekstil Tarihi Üzerine Araştırmalar. İstanbul: Türkiye İş Bankası Kültür Yayınları, 2008.

İnan, Göker. "XVIII. Yüzyılda Müderrislik Yapan Vak’anüvisler ve İlmiye S1nıfına Dair Tuttukları Bazı Kayıtlar.” Sahn-ı Semândan Dârülfünûn'a: Osmanlıda Ilim ve Fikir Dünyası (Âlimler, Müesseseler ve Fikrî Eserler) - XVIII Yüzynl içinde, ed. Ahmet Hamdi Furat, Nilüfer Kalkan Yorulmaz, Osman Sacid Arı, 295-312. İstanbul: Zeytinburnu Belediyesi Kültür Yayınları, 2018.

İpşirli, Mehmet. "Çömez." Türkiye Diyanet Vakfi İslam Ansiklopedisi VIII, 380. Ankara: Türkiye Diyanet Vakfi, 1993.

İpşirli, Mehmet. "Enderun." Türkiye Diyanet Vakfi İslam Ansiklopedisi XI, 185-187. Ankara: Türkiye Diyanet Vakfi, 1995.

İpşirli, Mehmet. "Kazasker." Türkiye Diyanet Vakfi İlam Ansiklopedisi XXV, 140143. Ankara: Türkiye Diyanet Vakfi, 2002. 
İpşirli, Mehmet. "Kıyafet (Osmanlı Dönemi)." Türkiye Diyanet Vakfi Íslam Ansiklopedisi XXV, 510-512. Ankara 2002.

İpşirli, Mehmet. "Osmanlı İstanbul'unda Geleneksel Eğitim ve Ulema.” Antik Çă̆’dan XXI. Yüzynla Büyük İstanbul Tarihi: Eğitim, Bilim ve Teknoloji içinde, ed. Coşkun Yılmaz, 34-85. İstanbul: IBB Kültür A. Ş., ISAM, 2015.

İpşirli, Mehmet. "Şeyhülislam," Türkiye Diyanet Vakfi İlam Ansiklopedisi XXXIX, 91-96. Ankara: Türkiye Diyanet Vakfi, 2010.

Jirousek, Charlotte. "Ottoman Influences in Western Dress." Ottoman Costumes: Frorm Textile to Identity içinde, ed. Suraiya Faroqhi and Christopher K. Neumann, 231-251. İstanbul: Eren Yayıncilık, 2004.

Jirousek, Charlotte ve Catterall, Sara. Ottoman Dress and Design in the West: A Visual History of Cultural Exchange. Bloomington: Indiana University Press, 2019.

Kallek, Cengiz. "Cübbe (Fıkıh)." Türkiye Diyanet Vakfi Islam Ansiklopedisi VIII, 103. Ankara: Türkiye Diyanet Vakfi, 1993.

Karababa, Eminegül. "Origins of a Consumer Culture in an Early Modern Context: Ottoman Bursa.” Doktora Tezi, Bilkent Üniversitesi, 2006.

Karaca, Filiz. "Hil'at." Türkiye Diyanet Vakf İslam Ansiklopedisi XVIII, 25-27. Ankara: Türkiye Diyanet Vakfi, 1998.

Karaca, Filiz. "Kürk." Türkiye Diyanet Vakfi İslam Ansiklopedisi XXVI, 568-570. Ankara: Türkiye Diyanet Vakfi, 2002.

Koca, Emine, "18. ve 19. Yüzyll Osmanlı Erkek Modası." Türk-İslâm Medeniyeti Akademik Araştırmalar Dergisi, 7 (2009): 63-81.

Koç, Fatma ve Koca, Emine. "Osmanlı Kanunlarında Giyim-Kuşam Yasakları." Türk-İslam Medeniyeti Akademik Araştırmalar Dergisi, 10 (2010): 31-50.

Koç, Fatma ve Koca, Emine. "Geleneksel Giysi Tarzlarının Değişimi ve Türk Modasının Oluşumunda İstanbul.” 7. Uluslararası Türk Kültürü Kongresi: Bildiriler IV: Türk ve Dünya Kültüründe Istanbul, 2167-2204. Ankara: Atatürk Kültür Merkezi Başkanlı̆̆ı, 2011.

Koçu, Reşat Ekrem. Türk Giyim Kuşam ve Süslenme Sözlügü̈. Ankara: Sümerbank Kültür Yayınları 1967.

Kökrek, Mehmet. “Osmanlı Serpûşları.” El Sanatlan 20, (2015): 46-53.

Kuper, Hilda. "Costumeand Identity." Comparative Studies in Society and History XV, 3 (1973): 348-367. 
Kumbaracılar, İzzet. Serpuşlar. İstanbul: Türkiye Turing ve Otomobil Kurumu [t.y.].

Küçükerman, Önder. Türk Giyim Sanayiinin Tarihi Kaynaklarn. İstanbul: GSD Dış Ticaret A.Ş. 1996.

Küçükhasköylü, Nurdan. "Osmanlı Kıyafet Albümleri (1770-1810)." Doktora Tezi, Hacettepe Üniversitesi, 2010.

Küpeli, Özer. "Revan Seferi’ne Götürülen Padişah Kıyafetleri." Cihannüma: Tarih ve Coğrafya Araştırmalan Dergisi II, 2 (2016): 33-74.

Kütükoğlu, Mübahat S.. Osmanhlarda Narh Müessesesi ve 1640 Tarihli Narh Defteri. İstanbul: Enderun Kitabevi, 1983.

Kütükoğlu, Mübahat S.. "1624 Sikke Tashihinin Ardından Hazırlanan Narh Defterleri." Tarih Dergisi 34 (1984): 123-182.

Mack, Rosamond E.. Bazaar to Piazza: Islamic Trade and Italian Art, 1300-1600. Berkeley, Los Angeles, London: University of California Press 2002.

Mardin, Ebü’l-ula. Huzur Dersleri: 2-3. İstanbul: İsmail Akgün Matbaası, 1966.

Marzolph, Ulrich ve Leeuwen, Richard van. The Arabian Nights Encyclopedia: 1. Santa Barbara: ABC-CLIO, 2004.

Maydaer, Saadet. "XVI. Yüzyılda Bir Osmanlı Müderrisi: Mevlana Muslihuddin Efendi ve Mirası." Uludağ Üniversitesi Illâhiyat Fakültesi Dergisi XX, 1 (2011): 117 155.

Maydaer, Saadet. "XVII. Yüzyılda Bursa'da Emekli Bir Kadı: Baldırzade Derviş Mehmed Efendi ve Serveti." Uludă̆ Üniversitesi İlahiyat Fakültesi Dergisi XVII, 2 (2008): 569-592.

Mazaheri, Ali. Ortaçağda Müslümanlarn Yaşayışlarn. Trc. Bahriye Üçok. İstanbul: Varlık Yayınları, 1973.

Mehmed Zeki. "Serpuş." Tarih-i Osmani Encümeni Mecmuası VIII-XI, 49-62 (19191921): 103-121.

Muslu, Ramazan. "İsmail Hakkı Bursevî’ye Göre "Libâs" Kavramı." Azîz Mahmud Hüdâŷ̂ Uluslararası Sempozyum Bildiriler Cilt II içinde, ed. Hasan Kamil Yılmaz, 339-355. İstanbul: Üsküdar Belediye Başkanlığı 2006.

Muslu, Ramazan. "Türk Tasavvuf Kültüründe Tarikat Kıyafetleri ve Sembolik Anlamları." EKEV Akademi Dergisi XII, 36 (2008): 43-66. 
Oral, M. Zeki. "Selçukîlerde Giyim Eşyası." Türk Etnografya Dergisi, V (1963): 1420.

Öz, Mustafa. "Ali Evlâdı." Türkiye Diyanet Vakfi İslam Ansiklopedisi II, 392-393. Ankara: Türkiye Diyanet Vakfi, 1989.

Özaydın, Abdülkerim. "Nizâmiye Medreseleri." Türkiye Diyanet Vakfi İslam Ansiklopedisi XXXIII, 188-191, Ankara: Türkiye Diyanet Vakfi, 2007.

Özaydın, Abdülkerim. "Vezir." Türkiye Diyanet Vakfi Islam Ansiklopedisi XLIII, 8287. Ankara: Türkiye Diyanet Vakfi, 2013.

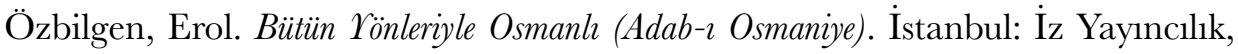
2004.

Özcan, Abdülkadir. "Cülûs.” Türkiye Diyanet Vakfi İslam Ansiklopedisi VIII, 108-114. Ankara: Türkiye Diyanet Vakfi, 1993.

Özcan, Abdülkadir. "Çorbacı." Türkiye Diyanet Vakfi İlam Ansiklopedisi VIII, 369370. Ankara: Türkiye Diyanet Vakfi, 1993.

Özcan, Abdülkadir. "Doğancı." Türkiye Diyanet Vakfi İslam Ansiklopedisi IX, 487489. Ankara: Türkiye Diyanet Vakfi, 1994.

Özen, Şükrü. "Kâdî Şureyh.” Türkiye Diyanet Vakfi İslam Ansiklopedisi XXIV, 119121. Ankara: Türkiye Diyanet Vakfi, 2001.

Özlü, Zeynel. XVIII. Yüzynln İkinci Yarısında Gaziantep. Gaziantep: [Gaziantep Büyükşehir Belediyesi], 2004.

Öztoprak, Nihat. "Divan Şiirinde Giyim Kuşam Üzerine Bir Deneme.” Divan Edebiyatı Araştırmalar Dergisi 4, (2010): 103-154.

"PabuçandMest: Shoes." 22 Mayıs 2019'da erişildi.http://www.issendai.com/16thcenturyistanbul/womens-garb-piece-by-piece/pabuc-and-mest-shoes/

Pakalın, Mehmet Zeki. Osmanl Tarih Deyimleri ve Terimleri Sözlüğ̈̈: 1. 3. bsm.. İstanbul: Milli Eğitim Bakanlığı 1983.

Pakalın, Mehmet Zeki. Osmanl Tarih Deyimleri ve Terimleri Sözlüğ̈̈: 2. 3. bsm.. İstanbul: Milli Ĕgitim Bakanlığı 1983.

Phillips, Amanda. "Ottoman Hil'at: Between Commodity and Charisma." Frontiers of the Ottoman Imagination: Studies in Honour of Rhoads Murphey içinde, ed. Marios Hadjianastasis. 111-138. Leiden, Boston: Brill, 2015.

"Prof. Dr. Reşat Öngören ile Söyleşi." Tasavouf: İmi ve Akademik Araştırma Dergisi 8, 20 (2007): 267-274. 
Quataert, Donald. "Clothing Laws, State, and Society in the Ottoman Empire, 1720-1829." International Journal of Middle East Studies XXIX, 3 (1997): 403425.

Rafaeli, Anat ve Pratt, Michael G.. "Tailored Meanings: On the Meaning and Impact of Organizational Dress." The Academy of Management Reviews XVIII, 1 (1993): 32-55.

Richardson, Connor H.. "The Coverings of an Empire: An Examination of Ottoman Headgear from 1500 to 1829." Gettysburgh College Student Publications. 104. 09 Nisan 2019'da erişildi. https://cupola.gettysburg.edu/cgi/viewcontent.cgi? $r e f e r e r=\&$ httpsredir $=1 \&$ article $=1$ 182\&context $=$ student_scholarship

Russell, Gül A.. "Physician at the Ottoman Court." Medical History, 34 (1990):243267.

Sakaoğlu, Necdet. "Osmanlı Giyim Kuşamı ve Elbise-i Osmaniyye." Tarih ve Toplum 8, 47 (1987): 36-41.

Sakaoğlu, Necdet ve Akbayar, Nuri. Derinin Anadolu'da Bin Yillk Öyküsü. İstanbul: Creative Yayıncılık ve Tanıtım, Orjin Grup, 2002.

Sandfuchs, Özlem Sert. "Reconstructing a Town from its Court Records: Rodosçuk (1546-1553).” Doktora Tezi, Ludwig-Maximilian Üniversitesi, 2008.

Sarıkçığlu, Ekrem. "Şeyhülislamlı Makamı." Atatürk Üniversitesi Illahiyat Fakültesi Dergisi 5, (1982): 197-218.

Schick, İrvin Cemil. "Tebdil-i Kiyafet, İrtidad ve İhtida." Acta Turcica, IV, 2-1 (2012): 36-45.

Serezli, Esad. "Şeyhülislamlar: İstanbul'un Fethinden Sonra." Tarih Hazinesi I, 5 (1951): 248-250.

Sertoğlu, Midhat. İstanbul Sohbetleri. İstanbul, Bedir Yayınevi, 1992.

Sevin, Nureddin. On $\ddot{U_{C}}$ Asırlı Türk Kiyâfet Târihine Bir Bakış. İstanbul: Başbakanlık Kültür Müsteşarlığı Kültür Yayınları, 1973.

Stillman, Yedida Kalfon. Arab Dress: A Short History: From the Dawn of Islam to Modern Times. 2. bsm.. Leiden: Brill, 2003.

es-Seyyid, Eymen Fuâd. "Fâtımîler." Türkiye Diyanet Vakfi İslam Ansiklopedisi XII, 228-237. Ankara: Türkiye Diyanet Vakfi, 1995.

Şeker, Mehmet. Gelibolulu Mustafa Âlî ve Mevầ'dü'n-Nefâis fi-Kavấdi’l-Mecâlis. Ankara: Türk Tarih Kurumu, 1997. 
Şeker, Mehmet. "Hil'at." Türkiye Diyanet Vakfi Islam Ansiklopedisi XVIII, 22-25. Ankara: Türkiye Diyanet Vakfi, 1998.

Şimşek, Halil. "The Missing Link in the History of Quranic Commentary: The Ottoman Period and the Quranic Commentary of Ebussuud/Abu alSu'ud al-'Imadi (d. 1574 CE) Irshad al-'aql al-salim ila mazaya al-Kitab al Karim." Doktora Tezi, Toronto Üniversitesi, 2018.

Talas, M. Asad. Nizamiye Medresesi ve İslâm'da Eğitim-Öğretim. Çev. Sadık Cihan, Samsun: Etüt Yayınları 2000.

Tatlısumak, Uğur. "Osmanlı Uleması ve Patronaj Illişkisi." Doktora Tezi, Selçuk Üniversitesi, 2016.

Tekin, Zeki. “Osmanlı Devleti'nde Kürk Ticareti.” Türkler X içinde, ed. Hasan Celal Güzel v. dğr., 754-763. Ankara: Yeni Türkiye Yayınları 2002.

Tez, Zeki. Tekstil ve Giyim Kuşam Sanatmnn Kültürel Tarihi, İstanbul: Doruk, 2009.

Tezcan, Hülya. "Ferace." Türkiye Diyanet Vakfi Íslam Ansiklopedisi XII, 349-350. Ankara: Türkiye Diyanet Vakfi, 1995.

Turan, Fikret. "İki Minyatürde Üç İstanbul Genci: 17. Yüzyıl Çarşı Resminde Gençlerin Giyimine Dair Tespitler.” Art-Sanat, 10 (2018): 280-292.

Turan, Illhami. Osmanh Kiyafetleri: Fenerci Mehmed Albümü=Ottoman Costume Book: Fenerci Mehmed. İstanbul: Vehbi Koç Vakfi, 1986.

“Türk Edebiyatı İsimler Sözlüğü.” 22 Mayıs 2019'da erişildi. http://www.turkedebiyatiisimlersozlugu.com/

Türkoğlu, Sabahattin. "Cübbe." Türkiye Diyanet Vakfi İslam Ansiklopedisi VIII, 102103. Ankara: Türkiye Diyanet Vakfi, 1993.

Uludağ, Süleyman. "Abâ." Türkiye Diyanet Vakfi Íslam Ansiklopedisi I, 4-5. Ankara: Türkiye Diyanet Vakfi, 1988.

Uzunçarşılı, İsmail Hakkı. Osmanh Devletinin İlmiye Teşkilâtı. 3. bsm. Ankara: Türk Tarih Kurumu, 1988.

Uzunçarşıll, İsmail Hakkı. Osmanh Devlet Teşkilâtından Kapıkulu Ocaklan: 1 - Acemi Ocağı ve Teniçeri Ocă̆ı. 3. bsm.. Ankara: Türk Tarih Kurumu, 1988.

Uzundal, Edip. "Osmanlı İlmiye Teşkilatından Bir Portre: Şeyhülislam Halil Efendi ve Terekesi." History Studies 10, 8 (2018): 177-196.

Ünver, Ahmet Süheyl. Türk Süsleme Sanatçllar Müzehhipler I. Yay. Haz. Gülbün Mesara ve Aykut Kazancıgil. İstanbul: İşaret Yayınları, 2007. 
Wilson, Elisabeth ve Haye, Amy de la. "Introduction." Defining Dress: Dressand Object, Meaning and Identity içinde, ed. Elisabeth Wilson ve Amy de la Haye, 1-9. Manchester, New York: Manchester University Press 1999.

Yağmur, Ömer. "De Turcarum Ritu Et Cereamoniis (1544) İçerisinde Bulunan Çeviri Yazılı Sözlük Üzerine.” VIII. Milletlerarası Türkoloji Kongresi 30 Eylül-04 Ekim 2013 Istanbul: Bildiri Kitabı II içinde, ed. Mustafa Özkan, Enfel Doğan, Fatih M. Sanca, 619-633. İstanbul: İstanbul Üniversitesi, 2014.

Yarcı, Güler. "Osmanlı Kürk Ticaretinde Bir Ölçü Birimi: Beden.” Beden Kitabı içinde, ed. Emine Gürsoy-Naskali ve Aylin Koç, 485-509. İstanbul: Kitabevi, 2009.

Yıldız, Hakkı Dursun. "Abbâsiler." Türkiye Diyanet Vakfi İslam Ansiklopedisi I, 31-48. Ankara: Türkiye Diyanet Vakfi, 1988.

Yıldız, Hasan. “Dârü'l-Hilâfeti'l-Aliyye Medresesi’nde Eğitim ve Öğretim.” Doktora Tezi, İstanbul Üniversitesi, 2017.

Yılmaz, Metin. "Emevi ve Abbasi Dönemi Resmi Kıyafetleri." Ondokuz Mayns Üniversitesi Illahiyat Fakültesi Dergisi XXVI, 26-27 (2008): 237-250. 


\section{Dizin}

A

Aba; 62, 90, 92, 96, 129, 141, 159, 170 , 189, 195, 204, 206, 208, 216

Abani; 136

Abbasiler; 60, 61, 62, 63, 64, 90, 104, 126, 218, 222, 248

Abdestlik; 114

Abdi; 175

Abdullah Efendi; 217

Abdullah-ı İlahi; 180

Abdülaziz Efendi, Karaçelebizade; 224,234

Abdülhamid, 2.; 141, 170

Abdülkerim Efendi; 195

Abdülmecid, 1.; 244

Acemi Oğlanları; 85
Acem Kalisi; 212

Acente; 129

Âdet; 64, 69, 82, 105, 108, 111, 161, 234

Ağa; 74

Ağabani; 101

Ağaç; 175, 214

Ahlak; 39

Ahmed, 1.; 109

Ahmed bin Abdullah, Müderris; 188

Ahmed Efendi bin İbrahim; 195

Ahmet Efendi, Müderris; 212

Ahşap; 128

Akçe; 104, 153, 160, 161, 195, 208

Akıncl; 119, 122 
Aksesuar; 39, 96, 108, 136, 140, 154, 242

$\mathrm{Al} ; 188$

Alaca; 188, 189, 202, 204, 216, 217

Alaeddin Bey; 65

Alaeddin-i Halveti; 66

Alaeddin Keykubad, 1.; 136

Alamet; 62, 63

Albrecht Dürer; 119, 122, 137

Albüm; 145, 198, 201, 230, 237

Alet; 122

Ali Bey, Evrenesoğlu; 158

Ali Efendi; 96, 217

Ali Kuşçu; 77

Altın; 70, 175, 188, 202, 212, 245

Amasya; 202

Ambras Kalesi; 97

Anadolu; 129, 158, 167, 229

Anadolu Selçukluları; 136

Angora; 128

Ankara; 129

Antropoloji; 39, 41

Anvers; 141

Araba; 144

Arap; 110

Arapça; 126

Arifi; 93

Arşiv; 46, 48, 69, 118, 167, 187, 236
Arz Odası; 236

Asa; 154

Asker; 65, 70, 73, 89, 244, 245

Askeri-i Edirnevi; 92

Askerî [Sınıf]; 42, 43, 70, 73, 74, 82, 96, 112, 114, 122, 202, 206, 212, 244, 247, 249

Askerlik; 74, 170

Astar; 118, 150, 154, 175, 208, 212, 242

Âşık Çelebi; 93, 170, 175, 179, 210, 212, 238

Âşık Paşa; 193

Aşki-i Kadim; 92

At; 159, 203, 221, 226, 237, 244

Atama; 64, 123, 218, 224, 229, 231, 234

Ataullah Efendi, Çivizade; 217

Atlas; 69, 70, 92, 115, 126, 128, 132, 195, 238, 242

Atölye; 61

Avrupa; 41, 51, 129, 247, 249

Ayak; 67, 88, 96, 118, 133, 136, 144, $145,150,151,158,165,201,210$, 212, 214, 221, 226, 229, 242

Ayakkabı; 69, 77, 85, 95, 96, 141, 144, 145, 150, 151, 158, 161, 165, 220, 230

Ayakkabıcı; 144

Ayasofya Camii; 100, 188

Aydınoğulları Beyliği; 202

Azmi-i Sani; 210 
B

Babadağı; 195

Babüssaade; 234

Bacak; 165

Bağclk; 85

Bağdadi Kaftan; 204

Bağdat; 61, 82

Bahar; 128, 214

Bahşiş; 73, 112, 114

Baki [Şair]; 175, 208

Banet Süad; 66

Bartolomeo von Pezzen; 52

Barut Rengi; 114

Baş; 62, 63, 88, 95, 101, 105, 108, 109, $110,127,158,159,165,175,176$, 179, 180, 198, 203, 208, 210, 215, 216, 218, 220, 221, 226, 229, 237, 242

\section{Başkent; 61}

Başlık; 62, 63, 65, 84, 88, 95, 96, 97, 100, 101, 105, 108, 109, 110, 159, 189, 195, 198, 206, 218, 224, 226, 237

Başmak; 69, 141, 145, 150, 201

Batı; 51, 242, 244

Batıli; 50, 51, 109, 237

Bayezid, Yıldırım; 89

Bayram; 105, 108, 202, 206, 236

Bayramlı; 115
Bel; 67, 77, 88, 112, 118, 123, 128, 129, 132, 133, 136, 137, 141, 164, $165,175,179,180,182,185,193$, 201, 206, 208, 210, 212, 214, 215, 220, 226, 229, 230, 242

Belediye; 189

Belediye Kanunları; 69

Belgrad; 73

Belik; 220

Benefşe; 188, 189

Benek; 202

Berat; 43

Beyani, Rusçuklu; 92

Beyaz; 60, 61, 65, 88, 89, 90, 97, 105, 108, 109, 123, 127, 136, 137, 165, 175, 176, 187, 189, 193, 195, 198, 201, 204, 208, 210, 212, 214, 215, 216, 217, 224, 229, 230, 231, 234, 236, 237, 238, 242, 244, 245, 249

Bez; 108, 109, 204, 206

Bıyı; 174, 176, 179, 193, 208, 210

Bilek; 67, 85, 112, 118, 132, 133, 136, 140, 165, 201, 208, 212, 214, 226, 230, 238

Bilezik; 188

Biniş; 67, 79, 82, 84, 88, 96, 111, 112 , $114,115,185,195,217,244$

Biniș-i Hümayun; 115

Biniş Merasimi; 115

Birun; 101

Biyografi; 41, 49

Bogat; 189 
Boğasi; 101, 104, 160, 188, 204

Boğaz; 140, 226

Bohça; 115, 234

Bordo; 210, 238

Borlu; 101

Bot; 141

Boy; 112

Boyun; 137, 140, 164, 175, 176, 208, 210, 220, 226

Börk; 96, 97, 217

Börkçüyan; 97

Börk-i Horasani; 84

Brit Düğme; 123, 136, 137, 214

Buhari; 59

Bursa; 67, 174, 195, 202, 204, 206

Buyruldu; 70, 79, 158

Buz; 216

Bürde; 59, 189

Bürokrasi; 60, 61, 66, 73, 74, 133, 159, 202, 244

Bürokrat; 65

Büyük Oda; 74

C

Came; 189

Cami; 62

Car; 115

Cebrail, Hz.; 100

Celaleddin-i Rumi, Mevlana; 84
Celalilik; 170

Celayi; 195

Cellabe; 59

Celse; 62

Cemiyet; 42

Cenaze; 109

Cennet; 100

Cep; 118, 201, 210, 220, 226, 230

Cepken; 96, 129

Cerrahbaşı; 88

Cerrahbaşılık; 88

Cesare Vecellio; 91

Cezayir; 137, 195, 217

Cilkave; 216

Cinsiyet; 40

Claes Rålamb; 145, 198, 230

Coğrafya; 64, 110

Cuma; 105, 224

Cübbe; 42, 43, 59, 61, 62, 64, 65, 66, 73, 74, 77, 79, 82, 85, 88, 89, 90, 92, 93, 96, 104, 110, 111, 112, 114, 115, 118, 122, 123, 133, 136, 137, $154,159,170,175,176,179,180$, 182, 185, 187, 193, 195, 203, 208, 210, 212, 214, 215, 217, 218, 220, 224, 234, 237, 238, 242, 244, 245, 249

Cülus; 73, 114, 155, 236

Cüz; 164

Cüz Çantası; 164

Cüz Kıllfi; 164 
C

Çadır; 104

Çakşır; 67, 69, 96, 115, 123, 129, 132, 136, 151, 165, 189, 193, 195, 212, 217

Çaprast; 74, 118, 122, 123, 175, 215, 221

Çavuş̧; 105

Çedik; 141, 151, 201, 220

Çelebi Medresesi; 203

Çılkafa; 195

Çizme; 141, 144, 145, 151, 195, 217, 226, 230

Çocuk; 42, 160, 164

Çop; 170

Çorap; 132

Çorbacı; 77, 85

Çömez; 110

Çubuk Dikiş; 110

Çuha; 69, 77, 85, 101, 114, 115, 128, 129, 185, 188, 189, 195, 203, 204, $208,216,217,218,226,234$

Çuhadar; 79, 189

Çuka; 217

\section{D}

Dai'd-duat; 222

Danişment; 110, 160, 166, 174, 182, 184

Daniyye; 63
Dava; 61, 62, 105, 153, 224

Davud Paşa Medresesi; 202

Defter; 48, 202

Defterdar; 101

Deniz; 204

Deniz Mavisi; 64

Deri; 145, 151, 201

Ders; 85, 90, 92, 111, 115, 141, 154, 165, 180, 202, 203, 206, 214

Dershane; 159

Ders Programı; 41, 78

Derviş; 93, 136, 166

Destar; 88, 93, 100, 105, 111, 115, 193, 195, 203, 204, 210, 212, 217 , 218, 221

De Turcarum Ritu Et Cereamoniis; 141

Devetüyü; 90

Dış Edik; 145, 165

Dikiş; 46

Diploma; 185

Diplomat; 109

Dirhem; 101, 104

Dirsek; 140, 193, 212, 221, 226

Divan; 100, 118, 229

Divanhane; 105, 224

Divan-1 Hümayun; 47

Divit; 104

Diz; 118, 132, 175, 187, 208, 212, 214, 220 
Doğanc1; 88

Doğu; 51

Dolama; 46, 74, 85, 118, 217, 226

Dolamali; 77

Dolap; 165

Don; 67, 82, 96, 188

Dua; 214

Düğme; 55, 85, 118, 122, 132, 133, $136,140,164,165,179,180,193$, 201, 210, 212, 220, 226, 230, 238

Düğüm; 230

Düğ̈n; 49

Dükkan; 100

Düztaban; 145

\section{E}

Ebubekir Efendi, Mevlana; 161

Ebu Muhammed el-Makrizi; 65

Ebussuud Efendi; 92, 231, 234

Ebu Yusuf; 63

Edik; 69, 96, 141, 144, 145, 150, 151, 220, 226, 229, 242

Edirne; 69, 150, 203, 210, 212

Eflatun; 123, 230

Ekonomi; 39, 73, 129, 244

El; 122, 210, 214, 220, 226, 230, 231, 236, 238

Elçi; 52

Elçilik; 50, 52
el-Hac Hasan Medresesi; 188

Elifî [Şalvar]; 133

Elmas; 140, 245

Elvan; 136

Emanet; 104

Emekli; 42, 189, 224

Emeviler; 61

Emir; 70

Emiri Sarık; 218

Emir Sultan; 166

Emlahu'ş-Şuara; 193

Enbiya; 100

Endaze; 208

Enderun; 74, 101, 165

Enderun Ağası; 79

Ense; 226, 230

Entari; 46, 82, 88, 96, 114, 115, 123, $132,133,136,154,165,175,179$, 180, 182, 187, 188, 193, 195, 201, 206, 208, 210, 212, 214, 215, 217 , 220, 221, 226, 229, 230, 238, 242

Entelektüel; 39, 40, 41

Erbabü'l-emaim; 222

Esad Efendi, Sahaflar Şeyhizade; 127

Esnaf; 82, 111, 136, 137, 144

Eşkıya; 47, 174

Etek; 140, 224, 230

Evliya; 216

Evliya Çelebi; 97

Eytam; 161 
Eyüp; 195

Eyüp Sultan; 244

Eyvan; 210

Eyyubiler; 112

Ezher Külliyesi; 89

F

Fakih; 63, 202

Fanila; 215, 216

Fars; 145

Fatıma, Hz.; 90

Fatımiler; 89, 222

Fenerci Mehmed Kıyafetnamesi; 220

Ferace; 69, 84, 96, 112, 114, 115, 118, 128, 180, 195, 212, 216, 217, 237

Ferecik; 195

Feridun Ulu Arif Çelebi; 84

Ferman; 70, 110, 128

Ferve; 123, 126, 158, 234, 236, 245

Ferve-i Beyza; 90, 123, 231, 236, 237, 242, 245

Fes; 88, 101, 160

Fetva; 111, 153, 245

Fikıh; 66, 140

Finansman; 41

Firaki; 176

Firengi; 224

Firengi Nihali; 212
Fiyat; 101, 104, 189

Fonksiyon; 95, 159

Formasyon; 153, 154

Fransız; 109

Futa; 176, 204, 220

Fütüvvet; 84

G

Gardırop; 189, 242

Gecelik Kavuk; 195

Geçit Resmi; 100, 220

Gelenek; 43, 126, 249

Gelibolu; 136

Gemi; 236

Geometrik; 198

Gezgin; 129

Gezi [Kumaş]; 185

Goodwin [James]; 201

Göbek; 123, 136, 137, 230

Göğüs; 214

Gömlek; 67, 77, 96, 132, 140, 161, 182, 187, 188

Gravür; 46, 50, 220, 226, 249

Gümüş; 175, 188

H

Hademe; 43

Hafiz-1 Acem; 208 
Haki; 238

Halali; 189

Halatü'l-Kahire; 110

Halayı; 203

Halep; 136

Halife; 62, 63, 64, 66

Halife [Ĕgitim]; 160

Halife [Tasavvuf]; 114

Halil Efendi, Şeyhülislam; 244

Halimi; 193

Hançer; 188, 212

Hanefi Efendi; 224

Harçlık; 166

Hardık; 160

Hare; 188

Harvani; 236

Hasan Çelebi; 179

Hasan, Hz.; 90, 218

Hasan Paşa, Molla; 180, 214

Hatai; 226

Hatifi; 119

Hatip; 43

Hayvan; 129, 158, 214

Hazinedarbaşı; 236

Hediye; 48, 59, 64, 65, 82, 90, 104, $115,185,202,231,234,236,245$

Heinrich Hendrowski; 52

Hekim; 88
Hekimbaşı; 88

Helaki; 212

Hıristiyan; 69, 109, 145

Hırka; 66, 84, 129, 185, 189, 204, 206

Hırsılık; 188

Hirt1; 150

Hilafet; 89

Hil'at; 48, 59, 65, 74, 85, 104, 111 , 126, 128, 129, 155, 158, 234, 244, 245

Hint; 82, 136, 237

Hint Kuşağı; 204

Hiyerarşi; 40, 58, 64, 65, 73, 74, 78, $96,104,167,242,248$

Hizmetçi; 203

Hizmetli; 43

Hoca; 110, 160, 214

Hoca Sadeddin; 100

Hocazade; 166

Hokka; 175

Horasani; 100

Hukuk; 42, 43, 187

Huzur Dersleri; 90, 115, 141

Hüseyin, Hz.; 90, 218

Hüsrev ü Şirin; 119

I

Innsbruck; 97

Islahat; 133, 187, 244 
Istilah; 43

I Turchi. Codex Vindobonensis 8626; 52, 122, 136, 137, 145, 161, 164, 221

i

İbn Battuta; 202

İbn Kemal; 158

İbrahim Paşa; 158

İbrişim; 204

İcat; 100

İcazet; 185

İcazetname; 248

İç Ağalar; 110

İç Donu; 96, 132

İçecek; 175

İç Edik; 141, 145, 150, 165

İç Gömleği; 67, 215

İç Kaftanı; 132

İçki; 193

İçlik; 133, 215, 216, 238

Ifta; 153

İhram; 193, 195, 217

İhsan; 65

İklim; 96

İkbahar; 160

İlm-i Firaset; 70

İm-i Kiyafet; 70
İmam; 42, 43

İmame; 63, 100, 189

İmameyn; 63

İmam-1 Azam; 100

Imamzade; 229

İmtihan; 66, 204

İmtiyaz; 43

İnam; 55, 155, 203, 245

İnamat Defteri; 224

Inci; 140

Ip; 238

İpek; 69, 70, 136, 137, 204

İplik; 140, 204

İade; 118

Iran; 61, 63

İshak Çelebi; 210, 212

İstanbul; 52, 69, 70, 78, 79, 97, 105 , 110, 128, 188, 202, 206

İstifa; 64

İstihdam; 153

İstinsah; 48, 92

İsyan; 167

$J$

Jacopo Ligozzi; 238

Jean Baptiste Vanmour; 161, 237, 238

Jean Brindesi; 224, 242 
$\mathrm{K}$

Kaba; 62, 92, 112, 129, 141, 170, 189, 212,216

Ka’b bin Züheyr; 66, 185

Kadı; 61, 62, 63, 69, 79, 92, 105, 110 , 118, 153, 154, 161, 175, 189, 193, 195, 202, 210, 216, 222, 249

Kadiasker; 55, 58, 101, 105, 123, 127, 153, 154, 158, 161, 217, 218, 222, 224, 226, 229, 230, 234, 237, 238

Kadı Kethüdası; 105

Kadı Sicilleri; 47, 165, 188, 195, 217

Kadı Şureyh; 61

Kadife; 70, 97, 202, 208, 224

Kadi'l-kudat; 222

Kadir Gecesi; 161

Kafesi; 101

Kaftan; 46, 48, 69, 84, 85, 88, 96, 111 , $112,115,118,119,122,126,155$, $158,159,165,180,188,193,195$, 198, 201, 204, 206, 208, 210, 214, 215, 221, 226, 229, 230, 238

Kahverengi; 179, 180, 208, 214, 220

Kakım; 82, 128, 158, 195

Kalça; 118

Kalem; 175

Kalemiye; 73, 74, 77, 89, 247

Kallavi; 100

Kalpak; 70, 159

Kamis; 62, 63, 96, 141, 201, 204, 206, 245
Kanun; 84, 90, 112, 114, 118, 153, 189, 231, 234

Kanunname; 46, 65, 84, 101, 224, 248

Kanunname-i Âl-i Osman; 74, 78

Kapama; 160, 161, 195, 217

Kapaniçe; 126

Kara Bali; 210

Karaman; 100

Karsak; 195, 217

Karsak Kafası; 217

Karyă̆dı; 110

Kasım Paşa Medresesi; 93

Kassam Defterleri; 212

Kastamonu; 216

Kaşkol; 137, 140, 175, 208, 210

Kaşmir; 85, 114

Katibi; 100

Kavuk; 88, 90, 95, 97, 100, 101, 104, $105,108,110,111,115,122,160$, 165, 175, 179, 195, 208, 215, 218, 226, 237, 238

Kaya Sultan; 100

Kebe; 96, 189, 195, 204, 206, 212

Keçe; 97, 100, 129, 189, 216

Kedi; 195, 217

Kehhal; 88

Kehhalbaşı; 88

Kemalpaşazade; 238

Kemer; 84, 141, 165 
Kemha; 70, 202, 204

Kenar; 141

Keten; 136, 188, 204

Kethüda; 105, 189

Kılabdan; 82

Kılıç; 104, 188, 244

Kırmızı; 65, 67, 70, 77, 84, 85, 88, 89, $97,101,137,145,165,175,176$, 179, 180, 182, 189, 202, 208, 210, 212, 216, 221, 224, 226, 230, 238, 242

Kış; 63, 88, 114, 128, 129, 189, 237

Kışlık; 85, 231, 234

Kilit; 188

Kisrevan; 82

Kisve; 61

Kitap; 41, 49, 51, 122, 141, 175, 179, 193, 195, 214, 221

Koğuş; 166

Kol; 67, 74, 85, 88, 112, 114, 118, 119 , 122, 133, 136, 158, 176, 179, 193, 198, 201, 208, 210, 212, 214, 215, 220, 221, 226, 238, 242, 245

Koleksiyon; 45, 46, 97

Kolluk; 119, 122, 158, 198, 208, 220, 221,238

Koltuk; 128, 129

Konak; 231

Konç; 141, 144, 151, 230

Kontoş; 84, 126, 188

Köle; 42
Kösem Sultan; 224

Krep; 85

Kronik; 46, 49, 229, 249

Kubadi; 100

Kudsizade; 229

Kufe; 61

Kulak; 63

Kumaş; 63, 67, 70, 78, 82, 85, 88, 97, 101, 108, 109, 115, 118, 126, 128, $129,132,136,137,140,159,170$, 175, 185, 193, 202, 203, 204, 206, 208, 210, 212, 214, 226, 229, 231, 234, 237, 238, 242, 245

Kumral; 204, 206

Kurşuni; 90

Kuruş; 208

Kuşak; 77, 82, 84, 88, 96, 105, 112 , 115, 123, 132, 133, 136, 137, 141, $160,164,165,175,179,180,193$, 195, 201, 204, 206, 208, 210, 212, 214, 220, 226, 229, 230, 238, 242

Kutnu; 69, 195, 217

Kutsal Roma İmparatorluğu; 52

Kuyruk; 158, 214

Küçük Oda; 74

Küçük Tepeli; 108, 179, 218

Külah; 88, 101, 104, 159

Kültür; 42, 60, 244

Künhü'l-ahbar; 166, 203

Kürk; 79, 82, 88, 112, 118, 123, 126, 127, 128, 154, 155, 158, 185, 189, 
193, 195, 201, 203, 204, 206, 208, 210, 212, 214, 216, 217, 218, 221, 226, 229, 230, 231, 234, 236, 238, 242, 244, 245

Kürsü; 214

L

Lacivert; 176, 179, 193, 208

Lakap; 78

Lata; 114, 123

Latifi Çelebi; 193

Levent; 167, 170

Libas-1 Eytam; 160

Libas Nizamnamesi; 83

Lütfullah Üskübi; 180

M

Maaş; 43, 204

Madenci; 43

Mağrip; 82

Mahkeme; 110, 111, 128, 161, 188, 195

Mahmud, 2.; 133, 244, 245

Mahmud Paşa; 77

Mahmuz; 226

Makrama; 165

Maliye; 48

Malzeme; 42

Mangal; 128
Mansip; 92

Manşet; 133, 193, 208

Masa; 210

Masraf; 48

Maşlah; 96, 244

Maşrapa; 188

Mavi; 88, 89, 90, 109, 141, 144, 189, 204, 216, 217, 220, 221, 242, 244

Meali; 193

Meclis; 158

Medine; 61, 193

Medrese; 41, 43, 45, 64, 65, 78, 90, $110,114,129,153,159,160,165$, $166,167,170,174,180,182,184$, 185, 187, 188, 248

Mehmed, 4.; 85

Mehmed Efendi; 195

Mehmed Efendi bin Abdullah; 195

Mehmed Efendi bin Sefer bin Abdullah; 161

Mehmed Efendi bin Süleyman; 195

Mehmed Efendi, Derviş [Baldırzade]; 189

Mehmed, Fatih Sultan; 65, 73, 74, 77, 78, 83, 84, 85, 101, 105, 214, 224, 248

Mehmed Said Efendi, Mirzazade; 234

Mehmed, Şehzade; 74

Mehmet Tahir Efendi, Şeyhülislam Kadızade; 245

Mektep; 160, 161 
Melami; 93

Melbusat; 55

Melbusat-1 Eytam; 160

Melihi; 193

Memlükler; 65, 90, 126

Memur; 43, 77

Memuriyet; 43

Meneviş; 217

Merasim; 73, 90, 105, 108, 109, 112, 123, 126, 159, 185, 206, 224, 226, 236

Merkup; 151

Mescit; 61, 104

Meslek; 42, 52, 55, 70, 100, 153, 189, 238

Mest; 70, 77, 96, 132, 141, 144, 145, 150, 151, 160, 165, 220, 242

Mest-i Çedik; 151

Mest-i Pabuç; 141, 201

Meşairü'ş-şuara; 212, 238

Meşihat; 43, 79

Mevali; 127, 159

Mevlana; 137, 155

Mevlana Babek; 202

Mevlana İshak; 203

Mevlana Muslihuddin; 206

Mevlana Samiri; 203

Mevleviler; 84, 140

Mevlevilik; 84
Mevlit; 127

Mevsim; 63, 88, 114, 133, 154, 159, $165,231,234,245$

Mezun; 153

Misır; 110

Millet Kütüphanesi; 238

Mimari; 41

Mintan; 46, 88, 114, 132, 133, 160, 217

Minyatür; 46, 48, 49, 51, 52, 110, 112, 136, 137, 140, 144, 145, 151, 154, 159, 174, 208, 212, 214, 237, 238, 249

Miras; 84, 161

Miskali; 101

Miyan-bend; 136, 245

Moda; 140

Molla; 110, 210, 214

Molla Alaeddin Ali et-Tusi; 85

Molla Fenari; 203

Molla Gürani; 208, 214, 215

Molla Hüsrev; 100, 159

Molla Kirmasti; 104

Molla Lütfi; 158, 159, 212

Molla Musannifek; 159, 208

Mor; 67, 89, 180, 189, 193, 208, 212, 238

Mouradgea D’Ohsonn; 236

Muafiyetname; 43 
Muhammed, Hz.; 59, 60, 65, 66, 89, 90, 108, 129, 185, 218, 220, 245, 248

Muhatap; 90, 115, 141

Muhyiddin Çelebiyyü'l-Fenari; 212

Muhzır; 189

Muid; 160

Muizz-lidinillah [Halife]; 89

Mukarrir; 90, 115, 141

Mukavva; 100

Mumcu; 105

Murad, 3.; 155

Murad, 4.; 151

Muslihuddin Efendi, Mevlana; 204

Mustafa Âlî, Gelibolulu; 70, 110, 166

Mustafa Efendi, Çeşmizade; 215

Mustafa Efendi, Konevi; 215

Mustafa Efendi, Memekzade; 229

Musul; 195

Mutarraş; 174

Mu'tazıd [Halife]; 62

Muvahhidi; 82, 127, 203

Mübettana; 65

Mücevherat; 244

Mücevveze; 100, 101, 105, 189, 218, 224

Müderris; 41, 42, 53, 64, 65, 73, 92, 93, 96, 104, 105, 110, 114, 118, 127, 137, 154, 159, 175, 182, 184,
185, 202, 203, 204, 206, 210, 212, 214, 216, 217, 224, 249

Müellif; 49

Müezzin; 43

Müftü; 153, 154, 198, 201, 202, 238, 249

Mühimme Defterleri; 46, 47, 78, 167

Mülazım; 179, 212

Müneccimbaşı; 88

Müneccimlik; 88

Müslim; 60

Müslim Çelebi; 210

Müslüman; 59, 60, 63, 64, 69, 109, 145,185

Müstain-Billah, Halife; 63

Müstear; 193

Mütevelli; 161

Müze; 45, 55

N

Nafe; 195, 216, 217, 224

Naima Mustafa Efendi; 185

Nakış; 129

Nakibüleşraf; 108, 127, 154, 218, 220, 221, 245, 249

Nakkaş; 49, 167

Nalbant; 166

Namaz; 224

Narh Defteri; 97, 101 
Nedim; 64, 65

Nefti; 195, 212

Nicolas de Nicolay; 220, 226, 238

Nihani-i Kadı; 92, 216

Nimten; 189

Nişan; 123

Nizamiye Medreseleri; 64, 66, 104, 248

Nizamname; 78, 187

Nizamülmülk; 62

Numani; 100

0

Oda; 165, 188

Ok; 122

Okçuoğlu Kürkü; 195

Okka; 101

Okulun Ilk Günü [Jean Baptiste Vanmour]; 161

Omuz; 63, 74, 85, 96, 108, 112, 136, 214, 220, 230, 238

Ordu; 144

Orhan Gazi; 89

Orta Asya; 84, 126, 136

Orta Doğu; 64

Ortakçı; 43

Osman Gazi; 65, 84

Osmanlı Arşivleri; 47

Osmanlı Devleti; 70, 79, 109 ö

Ödenek; 65

Ödül; 65

Öğrenci; 47, 65, 110, 129, 154, 159, $160,161,164,165,166,170,174$, 180, 182, 185, 187, 188, 214

Ömer, Hz.; 244

Önlük; 88

Örf; 97, 105, 144, 248

Örf [Başlık]; 90, 93, 95, 97, 100, 104, 105, 108, 127, 158, 189, 198, 208, 212, 218, 224, 226, 237, 238, 242, 245,249

Örfi Kavuk; 237

Örfi Sarı; 242

P

Pabuç; 70, 79, 96, 115, 141, 144, 150, $160,161,201,221,245$

Paça; 82, 132, 195

Padişah; 43, 88, 100, 123, 210, 231, 236

Pala; 93

Palto; 119, 129

Pamuk; 59, 67, 88, 101, 104, 105, 132, 204, 206, 215, 224

Pantolon; 67, 132, 133, 136, 161, 165, 187

Papazoğlu Medresesi; 188

Pardösü; 114

Paşakapısı; 105 
Patlak Dikiş; 111

Pavlo Verona; 244

Pazar; 111

Peçe; 193

Pedagoji; 41

Pelerin; 123

Pembe; 210

Penbe [Pamuk]; 101, 104

Perişani; 100, 105, 193

Perspektif; 51

Peştamal; 137, 175, 176

Piknik; 160

Polis; 188

Politika; 39, 51, 73

Post; 212, 224

Pot; 136

Potur; 132, 212

Puantiye; 158, 198, 214, 229

Puşi; 82

Püskül; 141, 212

\section{R}

Rahle; 214

Ramazan; 161

Ramazan Bayramı; 160

Ramazan Efendi, Behişti; 212

Raşit Efendi, Vakanüvis; 204

Reaya; 42, 43, 47, 67, 170, 247, 249
Renk; 42, 46, 47, 51, 58, 60, 62, 77, 78, $84,88,89,90,92,96,97,105,109$, $114,118,122,132,137,144,145$, $158,159,165,179,180,182,189$, 193, 201, 204, 208, 210, 212, 216, 218, 220, 221, 226, 230, 237, 238, $242,244,249,250$

Ressam; 46, 50

Rida; 220

Rodosçuk; 180

Rum; 59

Rumeli; 153, 155, 216, 229

Rumeli Kadıaskeri; 161

Ruus; 66

Rütbe; 83, 118

Rüzgar; 216

$\mathrm{S}$

Saç; 165, 220

Sadat; 218, 220

Sadrazam; 185, 234

Sahabe; 60, 89

Sahn-1 Seman; 73, 114, 174, 203, 249

Sahtiyan; 69, 141, 145, 151, 242

Sakal; 158, 159, 174, 175, 176, 179, 193, 208, 210, 212, 226, 238, 242

Saliha Sultan Vakfiyesi; 160

Salih Çelebi; 174

Samur; 82, 128, 189, 212, 216, 226, 231, 234, 236, 242, 245 
Sanat Tarihçisi; 119

Saray; 45, 48, 55, 61, 64, 74, 85, 88, 89, 100, 126, 154, 202, 224, 234, 236, 244

Sar1; 70, 77, 88, 89, 90, 136, 151, 165, 179, 189, 193, 195, 201, 210, 226, 230,242

Sarık; 43, 61, 62, 63, 64, 65, 69, 84, 85, 88, 90, 95, 96, 97, 100, 101, 104, $105,108,109,110,115,118,122$, 127, 154, 159, 165, 170, 175, 176, 179, 180, 185, 187, 188, 189, 193, 198, 201, 203, 208, 210, 212, 214, 215, 218, 220, 221, 222, 226, 229, 237, 238, 242, 244, 245, 249

Sarıkçı; 100

Sarıklı; 222

Satranç; 210

Sefer; 49

Selanik; 82

Selçuklular; 60, 64, 65, 84, 141, 222, 248

Selim, 2.; 73, 114, 155

Selimi; 100, 101

Selimi Kavuk; 55

Selim, Yavuz Sultan; 101, 193

Sembol; 39, 42, 89, 159

Semiyotik; 39

Semmur; 224

Seraser; 105, 126, 128, 204

Serbent; 108, 109

Seremoni; 231
Serhaddi; 188

Serin; 129

Serpus; 220, 226

Seyahat; 50, 167

Seyahatname [Evliya Çelebi]; 97

Seyfiye; 73, 74, 84, 247, 249

Seyyah; 202

Seyyid İlahi; 166

Seyyit; 90, 105, 218, 237, 245

Sibyan; 160, 161

Sibyan Mektebi; 160, 161, 164

Sicak; 129, 216

Sıdki Mustafa Efendi; 185, 206

Sinav; 204

Sinıf; 41, 187

Sırma; 108, 128, 137, 165, 236, 237

Sirt; 63

Sikke; 84

Silah; 122, 170

Sim; 126

Sincap; 128, 195, 217

Sipahi; 69

Siyah; 62, 63, 64, 88, 89, 90, 104, 109, 114, 123, 126, 141, 145, 158, 179, 180, 187, 193, 195, 198, 204, 206, 208, 214, 216, 217, 221, 229, 230, 244

Sof; 73, 85, 91, 101, 104, 114, 123, $129,195,212,217,236$

Softa Külahı; 110 
Soğuk; 119

Sonbahar; 128

Sopa; 170

Sorguç; 101

Sosyoloji; 41, 55

Sufi; 180

Suhte; 47, 154, 160, 165, 166, 167, $170,174,179,184,208$

Sultan; 42, 43, 49, 62, 64, 70, 73, 84, 85, 88, 104, 112, 126, 144, 155, 159, 203, 214, 224, 231, 234, 236, 245

Sun'izade; 229

Surname; 144

Surname-i Hümayun; 74, 100, 220

Su Samuru; 123, 195

$\mathrm{Su}$ Yeşili; 91, 208

Süleymaniye Darülhadisi; 153, 160

Süleyman, Kanuni Sultan; 73, 101

Süleymanname; 55

Süleyman Paşa; 84, 100

Sünnet; 65, 66, 108

Sünnet Düğünü; 74

Sünni; 62

Süruri Çelebi; 93

S

Şair; 48, 92, 93, 170, 212, 217

Şakaiku'n-numaniyye; 158, 175
Şal; 64, 77, 82, 88, 96, 101, 104, 133, 136, 137, 141, 166, 182, 185, 195, 215,242

Şali; 85, 195

Şalvar; 67, 77, 88, 115, 123, 132, 133, 136, 141, 165, 187, 221

Şam; 59, 61, 136

Şapka; 69

Şehinşahname; 155

Şehir Oğlanı; 174

Şehname-i Selim Han; 155

Şemail; 49

Şemdanizade Tarihi; 83

Şemle; 108, 109, 175

Şerif; 90, 218, 245

Şerit; 118, 237, 245

Şevketi Efendi, Eşref Efendizade; 187

Şeyh; 66, 140, 203

Şeyh-i İlahi; 180

Şeyhülislam; 55, 73, 89, 90, 105, 108, 123, 127, 153, 154, 159, 161, 185, 198, 224, 231, 234, 236, 237, 238, 242, 245, 249

Şeyhülislam Esad Efendi Vakfi; 160

Şeyhülislam Esad Efendi Vakfiyesi; 160

Şiir; 48, 93, 175, 179

Şiir Meclisi; 119

Şişe; 175 
T

Tabut; 100

Tac; 100, 154, 216

Tacir; 129, 238

Tafta; 101, 104, 216

Taht; 73, 109, 112

Tahta; 208

Takke; 84, 95, 96, 101, 110, 159, 166, $175,212,216$

Talebe; 90, 110, 137, 160, 161, 164, $165,166,170,174,175,180$

Tanzimat; 118, 245

Tarçın Rengi; 217

Tarha; 64

Tasavvuf; 66, 92, 114, 129, 140, 166, $170,179,203,212,216$

Tasvir; 45, 46, 48, 49, 50, 55, 67, 73, 74, 92, 144, 159, 166, 175, 179, 193, 198, 201, 203, 208, 214, 220, 242

Taşra; 128, 195, 242

Tatar; 84

Tavşan; 195

Tayin; 43, 123, 185, 224, 236

Taylasan; 63, 64, 96, 97, 104, 108, 214, 220, 238, 245, 249

Tebük Gazvesi; 59

Tedris; 153

Tefsir; 92, 231

Teftiş; 189
Tekalif; 43

Tekirdağ; 180

Tel; 70

Telhis; 231

Telif; 48

Tennure; 84

Tepeli; 104

Tepelik; 96, 158, 176, 221

Tereke; 47, 96, 150, 180, 189, 193, 195, 204, 206, 217, 244

Terk; 176, 226, 242

Terlik; 95, 96, 97, 110, 141, 176

Terzi; 112, 126, 128

Terzihane; 85

Tespih; 238

Teşkilat Kanunu; 74, 78

Teşrifat; 248

Teşrifatçı; 234

Teşrifat-ı Kadime; 127

Tevkii Abdurrahman Paşa; 84

Tezkire; 46, 48, 193, 212

Tiraz; 61, 126

Ticaret; 204, 206

Tiftik; 160

Tiftik Keçisi; 129

Tilki; 126, 189, 195, 217

Tilki Kafasi; 208

Topkapı Sarayı Müzesi Arşivi; 47 
Topuk; 67, 112, 145, 151, 201, 220, 230

Tören; 65, 96, 108, 115, 231

Trablus; 82, 136

Trabzon; 188, 195

Tiraş; 174

Tului; 170

Turuncu; 179, 189, 210, 230

Tuzcu; 43

Tülbent; 69, 84, 88, 90, 96, 97, 100, $101,105,110,115,136,175,204$, 214, 216, 217, 226, 237, 238, 242

Türk; 144

Türkçe; 85, 100

Türkler; 91, 100, 112

Türkmen; 216

$\mathrm{U}$

Ubeydi Çelebi; 175

Uçkur; 67, 136

Uhba; 64

Usta; 144

Usuli; 93, 179

Ü

Ücret; 184

Üç Etek; 88, 136

Üniforma; 42, 187, 250

Üniversite; 41, 249

Üsküf; 100, 105
V

Vakanüvis; 51

Vakfiye; 161

Vakıf; 43, 66, 110, 160, 161, 203

Vaşak; 158, 189, 212, 224

Velençe; 193, 216, 217

Veli; 161

Vergi; 43

Vezir; 70, 79, 82, 84, 97, 101, 104, 155, 158, 202

Veziriazam; 73, 105, 218, 224, 231

Y

Yağmurluk; 189, 193, 195, 212, 216, 217

Yahudi; 69, 70, 109

Yaka; 67, 82, 88, 114, 119, 122, 126, 132, 159, 164, 179, 201, 210, 214, 220, 221, 226, 229, 230, 242

Yanak; 63

Yaprak [Börk]; 97

Yarg1; 222

Yay; 122

Yaz; 63, 114, 128, 129, 245

Yazlık; 85, 231, 234

Yazma; 137

Yelek; 129

Yemek; 160, 184 
Yemeni; 88, 141, 145, 150, 216, 226, 242

Yen; 82, 85, 105, 112, 119, 136, 176, 185, 201, 208, 210, 212, 214, 221, 229, 231, 234, 236, 238, 242, 245

Yeniçeri; 74, 224

Yeniçeri Ağası; 69

Yeniçeri Ocă̆ı; 245

Yeşil; 88, 90, 105, 108, 109, 175, 176, 179, 180, 182, 187, 188, 193, 201, 210, 214, 216, 218, 220, 221, 226, $229,234,237,242,244$

Yıldız Sarayı; 141

Yırtmaç; 62, 88, 118, 132, 201, 210, 212, 221, 226, 238

Yusuf Efendi bin Halil Efendi; 193

Yusufi; 100, 101
Yün; 59, 92, 129, 136, 137, 140

Yüzük; 104, 245

Z

Zekeriya Efendi, Şeyhülislam; 161

Zerd; 189

Zerdeva; 204, 206

Zerdüşt; 109

Zeyrek Camii; 180

Zibin; 132, 160, 188, 195

Zirh; 108

Ziyaeddin Efendi; 123

Ziyafet; 236

Zülüf; 166 
